\title{
The Lost Shield Portraits of Aphrodisias. Reflections on Style and Patronage
}

\begin{abstract}
The paper re-examines a series of lost shield portraits discovered by Paul Gaudin in Aphrodisais in 1904 -1905. It focuses on three aspects of these objects: the technical details of the carving and choice of model (style), the structural specifications (manufacture), and the subject matter (iconography and theme). It endeavours to place these objects in the context of other shield portraits found more recently at Aphrodisias and to evaluate them in light of recent scholarship on late-antique sculpture. It stresses the similarities between these shield portraits and others from the site and reflects on possible contexts for the Aphrodisian shield portraits, considering for the first time the possibility that all of these Aphrodisian shield portraits might have come from the same context.
\end{abstract}

At Aphrodisias, a sprawling domestic building has been partially excavated to the north of the north building of the Sebasteion complex. The building was given the name the Atrium House in honour of its impressive atrium which features four ionic marble columns and two blue grey Corinthian columns with spiral fluting, a fountain, and mosaic floors. ${ }^{1}$ The excavated remains, especially the decorative elements, indicate that the house was refurbished and enlarged in the fourth century $\mathrm{AD}$ with more renovations in the fifth century $\mathrm{AD} .^{2}$ A peristyle court with an apse on its south side of this house seems to have been the location of series of marble shield portraits of cultural heroes that were part of a $4^{\text {th }}$ to $5^{\text {th }}$ c. refurbishment. ${ }^{3}$ These are exciting finds because three are of outstanding sculptural quality, because five are identified by a name inscribed along the lower rims of the shields, and because all are striking representations and reinterpretations made in Late Antiquity of models that date originally to the Hellenistic period. Nine (Table 1) have been masterfully published by R.R.R. Smith and have

\footnotetext{
${ }^{1}$ Lockey 2016. Campbell 1991, 22-26, calls it the Priest's House.

${ }^{2}$ Lockey 2016, 246-250, " $4^{\text {th }}-$ c. construction," and 247-251, " $5^{\text {th }}-c$. modifications".

${ }^{3}$ Lockey 2016, 252-253, fig. 15.11 for architectural setting. Lockey 2016, 251, considers the shield portraits to be part of the fifth-century additions.
} 
therefore become a benchmark for discussions of late-antique style and patronage. ${ }^{4}$ They demonstrate the range of sculptural production available and the desires of pagan literati of the later fourth to fifth century.

Seventy-seven years before the Atrium House was excavated (1904 vs. 1981-1987), Paul Gaudin had brought from Aphrodisias at least six shield portraits. Six were certainly stored in the Evangelical School in Izmir and were lost in the fire of 1922; another re-emerged in 1991 in Bornova, a northern suburb of Izmir. These two sets of shield portraits have been repeatedly discussed as two separate groups and cited as evidence for an Aphrodisian propensity to produce such shield portraits. ${ }^{5}$ This paper would like to re-present these Gaudin shield portraits and re-examine them in light of the finds at the Atrium House and in light of scholarly advances in the late-antique portrait studies, (both of which are heavily indebted to R.R.R. Smith). ${ }^{6}$

The paper thus presents an updated catalogue of the seven shield portraits of Gaudin from Aphrodisais; six (1-6) published by Lippold in 1929 and one (7) by Smith in 1995. This new catalogue focuses on three aspects of these objects: the technical details of the carving and choice of model (style), the structural specifications (manufacture), and the subject matter (iconography and theme). It understands style as mainly the prerogative of the workshop and sculptors; manufacture as economic and contextual considerations that involve patrons, builders, and sculptors; and subject matter as mainly dictated by patrons. Using this structure, the paper strives to evince the points in common between the lost shield portraits of Gaudin and those excavated in the Atrium House. The paper then briefly considers other groups of shield portraits that seem to be connected to the late-antique production at Aphrodisias. It seeks to determine precisely the aspects that can be associated with Aphrodisian shield portraits and whether there is a production of such items connected with Aphrodisias. In so doing, it also introduces a portrait head (8), recently on the art market, which belongs most probably to this genre of object and might be connected to Aphrodisias.

\section{Six shield portraits published in Photographischer Einzelaufnahmen antiker Sculpturen 1929}

Georg Lippold wrote a succinct but excellent description of the six medallions in the Evangelical School at Izmir. ${ }^{7}$ He noted that they were from Aphrodisias and late-antique in date. He presented the date as a fact not deduced from the stylistic qualities of the works but from the details of fashion presented by the portrait of the boy wearing a bulla. This is indisputable (see below). He also noted astutely the differences in the manufacture and layout of the frames and shields but he dismissed them, just as astutely, as probably due to a lack of atten-

\footnotetext{
${ }^{4}$ Smith 1990 and 1991a-b. The nine Atrium House shield portraits are presented in Table 1; the ninth, a blue marble frame on the shield of which was inscribed Aristotle and into which was set a separately worked bust. It is not discussed here in detail because it does not preserve a bust and because it is truly of different manufacture.

${ }^{5}$ Lockey 2016, 251, is the latest to do so: "The shield portraits ....may reflect a particular Aphrodisian specialty in lateantique marble production".

${ }^{6}$ In November of 2016, at the conference on style in Late Antiquity at the Norwegian Institute in Rome, I gave a paper on two portraits from Aphrodisias which I believed to be late antique versions of well-known types. One of these two portrait heads I identified as Menander and suggested belonged to a shield portrait. The essential part of that paper is Lenaghan 2018; what follows here is an expansion on the theme of shield portraits.

${ }^{7}$ Lippold EA 1929. Lippold 1918, 8, in discussion of Menander, added that there was also a "Göttin mit Turmkrone, ein Kind mit Stirnschopf, ein jugendlicher Kopf (Haare in die Stirn gekämmt, bulla) und ein bärtiger Kopf".
} 
tion to detail because he concluded the shield portraits must have come from the same context. He refrained, however, from any further speculation since little was known about the provenance.

Squarciapino presented these shield portraits again in 1943, and Cornelius Vermeule revisited them as a group in $1965 .{ }^{\circ}$ Although new finds at Aphrodisias have made some of Vermeule's comments outdated and his association of the portraits with members of the imperial family seems unlikely, he reiterated interestingly that the date of the objects was late Roman notwithstanding that "this seemed technically and stylistically impossible to believe." 9 The sculptural quality of these objects, transmitted in a few poor photographs, has now been overshadowed by the striking and extremely high quality of the new shield portrait finds from the Atrium House. Nonetheless, they provide useful evidence for a discussion of Aphrodisian late-antique style.

1. Shield portrait of Menander in rectangular frame. From Aphrodisias. (FIGS. 1-3)

Bibliography: Studniczka, 23, pl. 6.5. EA 3204-3205; Squarciapino 1943, 77 no. 1, pl. Rc; Richter 1962, 250-254, Beil. 71.5; Richter 1965, II 227, no. 3, fig. 1552/3; Vermeule 1965, 373, fig. 24; Winkes 1969, 245a; Sande 1982, 65; Fittschen 1991, 252, no. 70; Danguillier 2001, 253 no. 21; LSA 238 (Lenaghan 2018).

W of frame: $49 \mathrm{~cm},{ }^{10} \mathrm{D}$ of frame: $3.5 \mathrm{~cm}$; Distance of shield rim from lower frame: $5 \mathrm{~cm}$.

The extant fragment was preserved in two pieces; the right shoulder and adjacent shield and frame and the remainder of the bust, head, shield, and frame. Unmentioned by Lippold but visible in the photograph is a large break that runs vertically from the frame to the junction of the neck and right shoulder. The frame was well preserved below the shield in two fragments. The shield was preserved (clockwise) from behind the head around to the right shoulder. The bust and head were fully preserved. Above the right shoulder was the only extant area of the background of the shield. The back of the head appears to have been attached to the background. The eyes were marked; the pupils were a round drill hole and the iris was an incised circle around them.

The portrait was recognized by F. Studniczka as Menander, and the identification has been universally accepted; G.M. Richter affirmed its importance in 1962 and in the most complete discussion of Menander, K. Fittschen accepts it. ${ }^{11}$ The playwright is depicted in a himation and chiton. The edge of the himation falls along the inside of the left shoulder in a broad fold that is schematically rendered as doubled over itself. The chiton is visible over the chest and on the right arm. It falls in a series of mainly $U$ shaped folds that echo the neckline. The indentations between folds are shallow and rounded (a particularly large finger shaped one, with movement from the right shoulder towards the edge of the himation, is visible at the centre of the chest) and the peaks appear sharp-edged. The separation of the right arm from the body is denoted by a deep unbroken drill channel.

\footnotetext{
${ }^{8}$ Squarciapino 1943 altered some of Lippold's facts, presumably unwittingly. These are noted below. Vermeule 1965, 373-375.

${ }^{9}$ Vermeule 1965, 373.

${ }^{10}$ Lippold EA 3204-3205 gives the width of the "Grundplatte" as $49 \mathrm{~cm}$; Squarciapino incorrectly notes the diameter as $40 \mathrm{~cm}$.

${ }^{11}$ See Bibliography under $\mathbf{1}$.
} 
The portrait head and choice and arrangement of garments correspond to those of the famous seated statue of Menander in Athens which was used as a model throughout the Roman period. $^{12}$ The portrait itself is a simplified and intensified re-formulation of the Hellenistic Menander type (FIG. 3a). In 1965 Vermeule had already aptly summarized in English, "The head is a very free or general, but rather frozen, replica, of the well-known series." ${ }^{13}$ Menander's clean-shaven face has been thinned; the lines across the brow and the naso-labial folds have been emphasized; the hair that comes forward over the centre of the brow sweeps forward in a reverse $\mathrm{S}$ shape. Lippold and Richter well compared it to the shield portrait of Menander from Marbury Hall which was inscribed on the lower rim. I have recently compared it to another head (Menander?), excavated in the Atrium House (FIG. 3b). ${ }^{14}$ It is worth noting that all three heads, - the Izmir shield portrait, the Marbury Hall portrait, and the Atrium House - head share the same simplification of the hair pattern of Menander model and in this sharing differ from other late-antique versions. ${ }^{15}$ The brow reads (from viewer's right to left) a large downward $\mathrm{C}$ shape group of locks that disappears toward the ear, a triangular recess, an isolated central lock that comes forward, a significant triangular recess, and a $\mathrm{C}$-shaped group of locks that sweep behind the right ear. Above both ears, the locks are brushed backward and in front of both ears, the locks curl forward. The Evangelical School shield bust and the Marbury Hall shield bust are both dressed in the same manner as the original statue reconstructed by Fittschen. ${ }^{16}$

Lippold stated that the bust of this Menander shield portrait at the Evangelical School and that of the shield portrait of Pindar (2) at the School were similar. More specifically three shared details can be noted in the scant visual evidence. The doubled-over edge of the himation on the inside of the left shoulder has the same two defining folds; the same deep continuous channel divides the right arm from the bust; and the same raised fold on the right shoulder comes from back to front and slants toward the channel between the arm and the bust. A schematic drawing of the basic bust scheme shows these three details (FIG. 5). The fold patterns on the right shoulder appear also on a fragment found just east of the House (FIG. 7). The deep long drill channel between the arm and the body also appears on the bust of the boy wearing the bulla (3) (FIG. 8) and a fragment excavated in the great portico of the Atrium House $^{17}$ (FIG. 9a-b).

The vertical break at the right shoulder of this bust is a common point of weakness. This is the line along which the marble of the bust projects furthest from the background. The storerooms of Aphrodisias contain three shield bust fragments, from the Atrium House which have broken in more or less the same location from similarly-sized shield portraits. ${ }^{18}$ All of these bust fragments in Aphrodisias have been hollowed out behind so as to reduce the weight of the object. It is possible that Menander bust in Izmir was also hollowed out behind.

\footnotetext{
${ }^{12}$ Fittschen 1991.

${ }^{13}$ Vermuele 1965, 374.

${ }^{14}$ Lenaghan 2018. Marbury Hall is now Arthur M. Sackler Art Museum, Harvard University, inv. no. 1991.63: LSA 2109 .

${ }^{15}$ For other late antique versions, see Lenaghan in Smith and Ward-Perkins 2016, Chapter 21, 262.

${ }^{16}$ Fittschen 1991.

${ }^{17}$ Inv. 83-156. Found in the northwestern portico of the apsidal hall of the Atrium House.

${ }^{18}$ Inv. 83-156 noted above. Also inv. 69-314 and inv. 87-416 (FIGS. 6 and 7), see also below n. 25.
} 
Lippold gave the width of this shield portrait of Menander as $49 \mathrm{~cm}$. This is the only one of the shield portraits for which he lists a full width as opposed to width from edge to centre; presumably this is because this is the only shield portrait which preserved both bottom corners. The width of the shield portraits from the Atrium House at Aphrodisias vary from 53.5 (Pupil and Apollonius of Tyana), 54 (Alexander and PIndar), to $64 \mathrm{~cm}$ (Socrates). Five of the eight are less than $55 \mathrm{~cm}$ wide, and the average width, which takes into account the exceptionally large Socrates, of all eight is $56 \mathrm{~cm} .{ }^{19}$ This means that the Atrium House shield portraits are 4.5 to $7 \mathrm{~cm}$ wider ( 2.25 to $3.5 \mathrm{~cm}$ per side) than the width at the bottom of the frame of the Izmir Menander as given by Lippold. It also means that the diameter of the shield is probably much the same as that of the Marbury Hall shield portrait of Menander, the total width of which is listed at $48 \mathrm{~cm}$. The head of Evangelical School Menander appears to be the same size as a bearded head of a fourth to fifth century portrait which appears in the foreground in the same photograph (FIG. 1). ${ }^{20}$ These late antique heads are approximately $26 \mathrm{~cm}$ high.

2. Shield portrait of Pindar in rectangular frame. From Aphrodisias. (FIG. 4)

Bibliography: Lippold 1918 8; EA 3206: Squarciapino 1943, 77-78, pl. Rd; Vermeule 1965, 373 fig. 25; Winkes 1969, 245b; Sande 1982, 57, 60, no. 8, fig. 3; Bergemann 1991, 168; Danguillier 254 no. 25; LSA 602 (Lenaghan).

W from left edge to middle: c. $26 \mathrm{~cm}$, D of frame: $2.5 \mathrm{~cm}$; Distance of shield rim from lower frame: $6.5 \mathrm{~cm}$.

The frame was preserved only below the shield. The shield was preserved from lower left shoulder to above the lower the right shoulder. The bust and head were completely preserved. Above the right shoulder and adjacent to the left side of the neck, small areas of the background of the shield were preserved. Squarciapino notes that the "pupils were incised." 21

The portrait is a version of a type known to represent Pindar since the find of the inscribed Atrium House shield portrait in 1981 (Table 1.3); previously it was referred to as Julian the Apostate. $^{22}$ It shows a man with a full beard and medium-length hair that is cut around the ears. Both the hair of the head and the beard are generally straight with a slight bend. Over the brow, the hair clearly follows the arrangement of the original model; directly above the nose three locks come forward and bend to the proper right, and above the inner corner of the left eye is a parting after which the locks turn to the proper left. This is an accurate repetition of the hair detail of the original model. In contrast, the labelled shield portrait found at the Atrium House renders only the smallest of central partings in the hair above the nose and has unusual, symmetrically-placed, short-cropped locks over each temple which do not appear in the Evangelical School version. ${ }^{23}$ There are few distinctive facial details in the Evangelical school version. It seems, however, to lack the marked signs of age visible in some of the high-imperial representations of Pindar and well suggested in the Atrium House version

\footnotetext{
${ }^{19}$ Smith 1990, 131, gives $55 \mathrm{~cm}$.

${ }^{20}$ The head in the photograph is LSA 445. See LSA 2282 for a similar head at $26.5 \mathrm{~cm}$.

${ }^{21}$ Squarciapino may simply have made a mistake. See above n. 8 .

${ }^{22}$ For the portrait type of Pindar, see Bergemann 1991.

${ }^{23}$ Compare Smith 1990, pl. 7 with Bergemann 1991, pls. 30-31.
} 
which shows the lines above the nose, sunken eyes with loose skin beneath them, and deep naso-labial folds. ${ }^{24}$

This Evangelical School version shows a chiton and over it on the left shoulder a himation. This is a different arrangement of clothing than the Pindar shield portrait from the Atrium House presents; that bust shows ends of the himation over both shoulders. As noted above and by Lippold, the drapery of the Evangelical School bust is similar to that of the Menander (FIGS. 1, 4, 5). The three details (vertical edge of the himation, division of arm and chest, fold on the right arm) listed above in the description of Menander, recur here. The indentation beneath the diagonal fold from the corner of the neckline on the right shoulder to the centre of the chest is differently placed than that of the Menander. Nonetheless, it has the same proportions and aspect, a broad flat bottom with rounded walls. The folds of the chiton are more vertical than on the bust of Menander but are again sharp and low. Here (as above) it should be noted that the pattern of drapery, especially on the right shoulder and around the sagging neckline, repeats in two fragments of two different shield portrait from Aphrodisias (FIGS. 6 and 7). ${ }^{25}$ The one fragment seems to show a similar neckline with a flat-bottomed, finger-like fold running beneath it; the other fragment seems to give almost the exact same placement of the shoulder within the frame and the same raised fold that comes forward over the shoulder and the fine fold that descends diagonally along the outside of the chest.

The approximate width of the Pindar shield portrait as given by Lippold is c. 26 from outside edge to middle or c. $52 \mathrm{~cm}$ total. This width is virtually the same as the shield portraits of the Young Pupil and the Apollonius of Tyana of the Atrium House, both of which have a width of $53.5 \mathrm{~cm}$. The height of the head was probably also about $26 \mathrm{~cm}$.

3. Shield portrait of a boy wearing a bulla in rectangular frame. From Aphrodisias. (FIG. 8) Bibliography: EA 3207; Squarciapino 1943, 78, pl. Ra; Vermeuele 1965, 374 fig. 26; Winkes 1969, 245c; Sande 1982, 60-63, fig. 3; Goette 1986, 163 no. 5, LSA 605 (Lenaghan); Sande $2015,39$.

W from left edge to middle: c. $25 \mathrm{~cm}$, D of frame: $2.5 \mathrm{~cm}$; Distance of shield rim from lower frame: $2.5 \mathrm{~cm}$.

The frame was preserved in part along the shield around the proper right part of the chest; only a portion of the edge of the frame was preserved at the bottom. The lower portion of shield was preserved from the shoulders downwards. The bust and head were completely preserved. Outside the upper arms, small triangular areas of the background of the shield were preserved. The pupils were indicated.

The portrait shows a boy with a distinctive hairstyle and bulla. The medium length hair is cut around the ears and straight across the brow. The locks over the brow are styled in parallel $\mathrm{C}$ curves to turn to the boy's left. Two long locks of hair fall behind the ears on to the

\footnotetext{
${ }^{24}$ For example, in the Capitoline herm (Sande 1982, no. 1, fig. 1 or Bergemann 1991) and most particularly in the head in Oslo (Sande 1982, no. 4, fig. 2). The imperial-period version from Aphrodisias, Smith et al. 2006, 253-255, no. 157, pl. 109, shows only forceful lines above the nose into the brow.

${ }^{25}$ Fig. 6. Inv. 69-371 A. It was found during excavations in the area of the Theatre near the head of Pythagoras. For the find location of the head of Pythagoras: Smith 1991, 159. Fig. 7. Inv. 87-417. It was found in the area southeast of the House, over the steps that lead to the Temple of the Sebasteion.
} 
shoulders where they turn back to the neck. The boy's head turns to his left shoulder. The face is clean shaven with full, unlined cheeks. The neck is traversed by two Venus' lines.

The bust wears only one garment. It hangs in parallel folds. The folds are U shaped beneath the neckline and appear as straight diagonal lines that radiate from the area of the right shoulder onto the arms and outside of the pectorals. At the centre of the neckline it wears a round bulla with a loop attached to a stiffly circular necklace. There was probably some raised decoration at the centre of the bulla. The bulla is notably popular in representations of the third century and later. In these representations, it is not always worn with the toga, and it hangs on a stiff metallic circlet that differs from the leather cord of earlier representations. ${ }^{26}$

The arms are separated from the body by deep, long, uninterrupted drill channels; this connects it stylistically with the Menander and Pindar busts and also a fragment from the Atrium House (FIGS. 5 and 9). The radiating folds from the area of the right shoulder recall the right shoulder area of the bust of the Bornova shield portrait (7, FIG. 14). The round necklace also recalls vaguely the raised neckline of the chiton of the Bornova philosopher.

The approximate distance from the left edge to the middle is given by Lippold as $25 \mathrm{~cm}$. Although not visible in the picture, Lippold presumably gave this measure because there was preserved a portion of the original (viewer's) left edge. This measure clearly connects the shield portrait with the others in the Evangelical School and makes it, the portrait of a boy, $3.5 \mathrm{~cm}$ smaller than the smallest complete examples from the Atrium House.

Lippold noted the rim of the shield had a particular sort of platform or moulding, which distinguished it from the others at the Evangelical School. This detail appears and disappears on many of the shields of the Atrium House group. For example, the shield portraits of Alexander, Pindar, and Alcibiades feature it clearly but in the shield portraits of Pythagoras and Apollonios the moulded profile disappears around the top of the bust. A sizeable fragment of a shield rim and the area behind a left shoulder was excavated in 1982 at the Atrium House and does not fit with any of the published shield fragments. ${ }^{27}$ Although there are fragmentary shield portraits attested and not published, this particular fragment (FIG. 10) is interesting in connection to this lost shield portrait of a boy. It has a width of 26-30 cm depending on the position in which it is held. It has a pronounced lip or ledge where the round shield connects to the background; it has a few centimetres of empty background space on the outside of the shoulder; the long horizontal shape of the break and the engraved line on the background of the fragment which must correspond to some representational detail (shoulder or hair) align well with the break of the lost shield portrait. This entirely hypothetical exercise demonstrates an important possibility that has never been considered and will be discussed below: Could these shield portrait busts lost at the Evangelical School in Izmir have come from the same context as those in the Atrium House?

Of all the shield portraits of the Evangelical School this is perhaps the most important because it is thematically the most particular and because it was used by Lippold as the object that most securely dates the group to the fourth century AD but without discussion. Ver-

\footnotetext{
${ }^{26}$ Goette 1986 lists 7 examples in appendix IIb of representations (in all media) of the bulla worn without the toga to which others can be added. See Lucchesi-Palli 1995 or Krumeich 2005/2006. Goette 1986, 146 notes that the flat band on which the bulla was worn in the early imperial period is replaced by a necklace in the third to fourth centuries.

${ }^{27}$ Inv. 82-91. at the southeastern corner of the apsidal hall and the corridor adjacent to it.
} 
meule's suggestion that it is a portrait of Constantine is untenable. ${ }^{28}$ Sande, both in 1982 and in 2015, has well noted its pertinence to a long tradition of boys involved in religious service. It is both the hairstyle, the "Camillus-frisur/Camillus coiffure" and the simple sleeved tunic (which is less emphasized by Sande) that are typical for boys in ceremonial religious service. ${ }^{29}$ Compelling comparanda are a statue type, known in several Roman marble copies and connected with the Eleusinian Mysteries, and the boys (with a notably cut and curving fringe) who carry the table laden with spoils on the Arch of Titus. ${ }^{30}$ The frequent appearance of the "Camillus" type in Roman public art in the first to second centuries and the drilled eyes of this portrait led her to date the Evangelical School shield portrait in the Hadrianic period. Yet, she notes also that the tradition, the curving, combed forward, fringe and the shoulder locks combined with the simple tunic continue in representations of boys in the fourth century and later. These late-antique boys - for example one wearing a beautiful chiton and holding the cloak of his master on a mosaic in the frigidarium at Piazza Armerina -, have been discussed by Balty as paedogogiani, finely schooled boys who were testimonies to the nobility and learning of the family in which they served. ${ }^{31}$ Similar boys appear clearly in the Missorium of Theodosius and the Obelisk of Theodosius in Istanbul, dated securely to ca. AD $400{ }^{32}$ Particularly the reliefs in marble on the base of the Obelisk are comparable; several young men in the entourage have similar hairstyles, wear round bullae on metallic circlets, and are in thin tunics which have vertical folds. ${ }^{33}$ The presence of a bulla significantly indicates that these boys were not necessarily slaves but free-born Romans. Thus, the Evangelical School shield portrait can either be interpreted as a free-born, upper-class child with a traditional religious duty or as a free-born, upper-class child learning and serving in the home of a recognized master. ${ }^{34}$ The meanings are in fact not mutually exclusive.

4. Shield portrait of goddess with diadem and mural crown, Tyche or Polis. From Aphrodisias. (FIG. 11)

Bibliography: EA 3208; Squarciapino 1943, 78, pl. Rb; Vermeule 1965, 375, fig. 27; Winkes 1969, 246d; Sande 1982, 73; LSA 605 (Lenaghan).

W from left edge to middle: c. $27 \mathrm{~cm}$, D of frame: $4 \mathrm{~cm}$; Distance of shield rim from lower frame: $2 \mathrm{~cm}$.

The rectangular frame was missing only its upper border and a small portion of the sides adjacent to the upper border. Also only the upper part of the shield was missing. The bust and head were well preserved. Notably the nose, lips, and crown appeared intact. The pupils were described as plastically rendered which implies that they were raised disks.

\footnotetext{
${ }^{28}$ For Vermeule, see Bibliography under $\mathbf{3}$.

${ }^{29}$ For Sande, see Bibliography under 3. For statue type and discussion of the figure on Arch of Titus: Sande 2015, 20-21 with n. 82, fig. 6 , and 31, fig. 11 .

${ }^{30}$ For statue type and discussion of the figure on Arch of Titus: Sande 2015, 20-21 with n. 82, fig. 6, and 31, fig. 11. The version of the statue illustrated by Sande at fig. 6 was found on the Quirinal in 1901: Helbig ${ }^{4} 1966,318-319$, no. 1503.

${ }^{31}$ Balty 1982, 307-312 and pl. 30 fig. 5 for the mosaic of Piazza Armerina.

${ }^{32}$ For the Missorium: Almagro Gorbea 2000.

${ }^{33}$ For the Obelisk: Bruns 1935, figs. 64, 66, 67. Also compare a herm at Welschbillig: Wrede 1972, no. 69, pl. 35.1.

${ }^{34}$ Sande 2015, 334.
} 
The head wears a tall diadem and above that a mural crown; this identifies the subject as Tyche or Polis. ${ }^{35}$ The head turns to its right; the face is oval with regular features and full cheeks. The hair is parted at the centre and swept back off the face, covering the tops of the ears. A small C-shaped lock falls in front of the ears.

The bust wears a chiton, the ample neckline of which slips down on to the left shoulder. As with the Menander and Pindar, the shield portrait seems to rely, albeit loosely, upon a model. The bust is a version of the Hera Borghese type that resembles the Hera Barberini closely (FIG. 11). ${ }^{36}$ The Hera Barberini, which was found in Rome, shows a chiton of heavier material than the other examples and a diadem on the head. The edge of the chiton of the Evangelical School shield portrait is bunched in two folds on the right side. It curves over the top and down the side of the left breast in a broader band. At the left armpit it curves downward but then rises again at the upper arm. This as well as the U-shaped folds between the breasts and the nipple that emerges through the chiton borrow from the well-known model. The diadem on the head appears on the Hera Barberini but is not usually associated with the model. The point remains, however, that the model or general framework for the scheme of this shield portrait was a traditional Classical one.

Stylistically the bust shows the same handling of the straight folds originating on the right shoulder and the U-shaped folds beneath the neckline as the Bornova shield bust (7) (FIG.14). The locks of hair appear to be separated by deep drill channels in the area of the temples; this was noted also by Vermeule. In the lock above and in front of the ear one can see also small "bridges", fine marble struts, over the drill channels (FIG. 10). This is a characteristic of the workmanship of the best carved and most impressive shield portraits of the Atrium House. The shield portrait of a bearded man, the Old Philosopher, shows similarly worked hair and perhaps even ear with a prominent hollow in the outer shell (FIG. 13).

Lippold gave the measures of this shield portrait as slightly larger than the others - its width is approximately $54 \mathrm{~cm}$. This may be due to its fuller preservation but in any case it makes it, without interpretation, the same size as five of the Atrium House shield portraits (Young Pupil and Apollonios W: 53.5; Alexander and Pindar W: $54 \mathrm{~cm}$; Alcibiades W: 55 $\mathrm{cm})$. Also the distance between the rectangular bottom edge and the shield frame is small, 2 $\mathrm{cm}$. This detail recurs in the Alexander shield portrait of the Atrium House, but it should be duly noted that the distance between frame and shield varies in those portraits also. ${ }^{37}$

5. Shield portrait with bust of child probably wearing youth-lock

Bibliography: EA col. 52 no. 33; Squarciapino 1943, 78 no. 5; Vermeule 1965, 375; Sande 1982, 73; Winkes 1969, 246e.

H. 55, W: 43, D of background: $3 \mathrm{~cm}$. Distance of shield from lower edge: $4 \mathrm{~cm}$.

Lippold makes only two observations about this object of which no photograph is preserved. First, the framing background was entirely preserved. Second, the pupils were plas-

\footnotetext{
${ }^{35}$ The curving edge of the drapery (but not its style) and the diadem with mural crown appear on a relief figure of the first-century grave monument of C. Zoilos at Aphrodisias. that figure is labelled Polis: Smith 1993, 36, no. 5, pls. 15-17.

${ }^{36}$ Hera Borghese: Moltesen 2002, 42-45: Bieber 1977, 47-49. Hera Barberini: Lippold 1956, 126-128, no. 546.

${ }^{37}$ The different distances between the rectangular bottom edge and the shield of the Atrium House portraits is best appreciated in Smith 1996, figs. 77-78.
} 
tically rendered ("Augensterne plastisch"). Squarciapino speaks of a "bulla" but this is nowhere else confirmed.

The portrait showed a child with a quiff and a twisted lock hanging to the side ("mit Stirnschopf und gedrehter Locke"). Lippold did not associate this shield with a divinity (Cupid or Harpocrates) but he also did not mention clothing which leads me to assume that the child was nude. Vermeule's association of the bust with an imperial child (Licinius II, Dalmatius, or Hanniballianus) is entirely untenable. Sande's observations about the identity are of greatest interest. In the context of the portrait of the boy with the bulla $(3)$, she notes that the boy is best understood as wearing a youth- lock (also referred to as an Isis lock or a Harpocrates lock). ${ }^{38}$ This sort of lock appears in portraits of boys throughout Roman Empire and reached its height of popularity in the west in the third century AD. ${ }^{39}$ It is associated with Isis or mystery cults; the boys who wear them have been dedicated by their parents to the worship of a divinity. Moreover, the epigraphic evidence suggests that boys who wear them are mainly infants and certainly under ten-years old. ${ }^{40} \mathrm{C}$. Hallett in his discussion of a marble portrait statue of a boy from Aphrodisias wearing this youth-lock of hair suggests that the boy was dedicated to the service of Aphrodite and perhaps the Aphrodite of Aphrodisias might have been assimilated with Isis. He concludes in regard to that statue, "the youth lock should probably be understood as a mark of status as well of religious devotion." 41 The interpretation of the shield portrait should be much the same; an infant of status and dedicated to religious service. This portrait and the portrait of the boy wearing the bulla (3) might then provide portraits of two boys at different ages and probably in traditional training and servitude to a divinity.

The dimensions given by Lippold make this shield the smallest of the Izmir and Atrium House busts. The size may relate to the subject who from the hairstyle should be an infant. The subject, an infant, was probably related to its placement in a less prominent position (a "tighter corner") in the final display.

6. Female head with a diadem from a shield portrait

Bibliography: EA col. 52 no. 32; Vermeule 1965, 375; Winkes 1969, 246; Sande 1982, 73-74. No measures. Only head preserved.

One can only imagine that the head was similar to no. 4. It probably represented a goddess rather than an empress since Lippold makes no mention of a hairstyle. ${ }^{42}$ For that same reason, one should imagine that it had long hair that was centrally-parted and pulled back over the ears. That Lippold recognized it as a shield portrait suggests that either some portion of the back of the head touched against a relief (see discussion under 8) or that it was markedly close to 5 .

\footnotetext{
${ }^{38}$ For a discussion of this lock in the context of Aphrodisias, see Smith et al. 2006, no. 42, 161-162 (C.H. Hallett) with references at his n. 6 .

${ }^{39}$ Goette 1989, 206.

${ }^{40}$ Hallett in Smith et al. 2006, 161, n. 8. His information is from Goette 1989, 209.

${ }^{41}$ Hallett in Smith et al. 2006, 161.

${ }^{42}$ Sande 1982, 74, arrives similarly at this conclusion. Vermeule, in contrast, would like to see it as Helena or Constantia but both date and subject seem unlikely to me.
} 
It is interesting to note that two fragmentary shield busts of female divinities were found in 1975 in a secondary context to the east of the South Agora at Aphrodisias. ${ }^{43}$ One shows a female with a chiton draped in the same manner as $\mathbf{5}$, though with much less attention to rendering realistic movement in the folds. The other shows a female wearing a chiton fastened only on the right shoulder; the upper edge of the chiton falls diagonally, revealing the left breast. They are both small and would have had a restored width of about $45 \mathrm{~cm}$. Also worthy of note is that the right side of a shield bust (restored width of ca. 56) was found in two pieces in the southwest area of the Sebasteion and represents a female. ${ }^{44}$ Because the clothing is traditional, a himation over a chiton, the subject could have been either divine or mortal. In any case, these three fragments are evidence of shield portraits of female subjects on two slightly different scales and all from secondary contexts the southwest of the Sebasteion complex.

7. Shield portrait of Bornova-Heidelberg type in rectangular frame. From Aphrodisias? Rediscovered in Bornova in 1991 (FIGS. 14-15)

Bibliography: Smith 1995, 332-335, pls. 77-8; Smith 1996, 63-65, fig. 66; Danguillier 2001, 153-4; LSA 236 (Lenaghan).

H: 61.5, W: 57.5 , D: $25 \mathrm{~cm}$. H (chin to crown): $27 \mathrm{~cm}$.

The frame and head are preserved in much the same manner as the Pindar shield portrait (2) was. The frame is preserved only below the shield. The shield was preserved from lower left shoulder to the lower the right shoulder. The bust and head were completely preserved. Above both shoulders, small areas of the background of the shield are preserved. The bust has not been hollowed out behind. ${ }^{45}$

The portrait head has been identified as a version of a type now known as the Bornova (after this object) - Heidelberg type. The bust wears a sleeved chiton with a rounded neckline that sags at the centre, and a himation hanging vertically over the left shoulder. The inner border of the himation is represented differently from that of the Menander (1) and Pindar (2). Here the folded edge of the himation has expanded in breadth and its hemmed bottom edge echoes the curving line of the shield's frame. This is a simplification of the mode of dress seen in the Pythagoras shield portrait from the Atrium House; in that Pythagoras bust the main portion of the himation is worn diagonally from the left shoulder to the right chest.

Smith has deemed this shield portrait to be connected neither to the workshop of the Evangelical School nor to that of the Atrium House. ${ }^{46}$ There are differences but a few similarities and circumstances make it a difficult judgement. Although the arrangement of the himation of the Bornova bust differs from the Menander and Pindar formerly in the Evangelical School, the rendering is much the same. The low areas between the folds are flat with rounded walls; the particularly large finger shaped indentation beneath the neckline appears again here. The straight folds have sharp-edged peaks which are triangular in section. The U-shaped

\footnotetext{
${ }^{43}$ Inv. 75-30 and 75-31.

${ }^{44}$ Inv. 79-173 and T-205. The upper shoulder fragment was published mistakenly as a bust in Smith et al. 2006, 248, no. 148.

${ }^{45}$ The Atrium busts are mainly hollowed out behind the bust. Yet the Alexander and the Socrates are not.

${ }^{46}$ Smith 1996, 65.
} 
folds across the breast, in fact, recall those on the shield portrait of the goddess (4). The style of the head seems also in keeping with the Menander and Pindar; it lacks the exciting sharpness of the finest shield portraits of the Atrium House but repeats a model with attention to detail.

The width of this shield portrait $(57.5 \mathrm{~cm})$ is larger than all of the former Evangelical School portraits. It is wider than all but two of the fully preserved shield portraits from the Atrium House; the unfinished Socrates shield portrait is $64 \mathrm{~cm}$ wide and the more comparable shield portrait of the unknown bearded man, the Old Philosopher, is $58 \mathrm{~cm}$ wide.

This shield portrait came to light in a secondary context, a school room, in Bornova, a suburb of Izmir. It was connected with Aphrodisias because Paul Gaudin an earlier excavator of the site had brought finds to his villa in Bornova. This connection provides it easily with a context that makes sense; it was one of a group in a city where shield portraits of philosophers are known. In turn as one of the Aphrodisian shield portraits, it strengthens the connection to a group of shield portraits of philosphers found in Rome amongst which there is probably a shield portrait of the same Heidelberg-Bornova type and a portrait of Menander, inscribed on its shield and similar typologically to the one lost at the Evangelical School. ${ }^{47}$

\section{Manufacture, style, and iconography of Gaudin shield portraits in context of Aphrodisias}

In terms of manufacture all of the seven shield portraits associated with Gaudin share two main characteristics. First, they are made in the same block of marble as their rectangular background and, second, the shield rim has a simple profile (maximally it has a cyma moulding) and an undecorated surface. Within these two broad similarities, there are variations in the structural specifications. The size varies; they range from $43 \mathrm{~cm}$ wide (the unillustrated child, 6) to $54 \mathrm{~cm}$ wide (the female divinity, 4) to $57.5 \mathrm{~cm}$ wide (the Bornova philosopher, 7). The shield is set from between $2 \mathrm{~cm}$ (the female divinity, 4) to $6.5 \mathrm{~cm}$ (Pindar, 2) from the bottom edge of the rectangular frame. The rim of the shield of the boy with the bulla (3) had a moulded edge; the others emerged continuously from the backdrop and were undecorated.

Inside the shield was a portrait bust, the back of the head of which seems to have been attached until the area above the ears. Given the measures listed by Lippold and the relative size of other objects in the photographs, one can estimate loosely the measures of the heads. ${ }^{48}$ The head of the boy with the bulla (3) might have been as small as $20 \mathrm{~cm}$ from chin to crown and that of Pindar (with beard, 2) ca. $25 \mathrm{~cm}$ from chin to brow; the head of the goddess (4) from chin to the top of the diadem was probably larger, $27 \mathrm{~cm}$. The head of the bearded Bornova shield portrait (7) is $27 \mathrm{~cm}$.

The style of the eye markings may vary; the rendering of the hair and drapery folds is perhaps more consistent. The eyes of Menander consisted of a pupil made by a deep drill hole and encircled by an engraved iris; the pupils of the boy with the bulla are noted as marked (and so perhaps similar to Menander's); those of the goddess and the infant were said to be "plastically rendered" which might suggest a raised disk or a drill hole. The hair of the Menander (1), Pindar (2), boy (3) and Bornova philosopher (7) is defined in broad locks separat-

\footnotetext{
${ }^{47}$ For Heidelberg portrait from Rome, see Bergmann 1999, 52, no. 2. For Marbury Menander, see above n. 14. For group, see below n. 60 .

${ }^{48}$ Lippold's measures and measuring points vary. He perhaps did not have total access to the objects or more probably was seeking measurements from fixed extant points of the objects.
} 
ed by drill work. Deep drill work appears most clearly in the hair around the temples of the Menander (1) and of the goddess (4). In this latter head, the channels are crossed by marble "bridges", small areas where the marble has not been drilled away.

The drapery is rendered schematically; that is, folds tend to follow parallel patterns and be simple. The form of the body models the chiton. Certain patterns notably repeat. The raised peaks of the thin inner garments are sharp arrises, and the depressions between folds in these thin garments are broad and flat-bottomed.

The subjects of the seven Gaudin shield portraits are wide-ranging but distinctly of traditional classical character. The subjects are three philosophers all of which employ versions of known portrait types (Menander, Pindar, and Bornova-Heidelberg), two boys (one probably an infant and one a child, both with religious functions), and two divinities. For all of the subjects about which we can judge and with the exception of contemporary portrait of the boy (3), the sculptors have worked with classical models or within a classical framework. The Atrium House shield portraits are notably seven philosophers which follow classical models, among them Pindar (and possibly Menander) as well as two portraits (a bearded mature man, the Old Philosopher, and a young man, the Young Pupil). The countenances of the classical models appear to be interpreted with less attention to specific facial details; that is, wrinkles, cheekbones, jaw-lines seem smoothed and air-brushed.

These observations confirm the main conclusions of Lippold and of Smith, both of whom in their own way noted a tolerance for technical variation, stylistic and structural, among contemporary shield portraits within one group or context. ${ }^{49}$ Smith divided his eight into a "main series", those of excellent quality, and a secondary series; the ninth, the Aristotle was a bust set into a blue grey frame and thus, completely different from all the others. He considered the six of the main series to belong to a single commission and to have been made at one time which was clearly in the later fourth or early fifth century. We can perhaps refine Smith's suggestion regarding the commission of the Atrium House. Particularly the Evangelical School shield portrait of the boy with the bulla (3) and that of the goddess (4) have aspects of Smith's main series; the moulded rim and the fine bridges in the hair. Thus, we note that neither the Evangelical School group nor the Atrium House is purely of one series or hand and that both groups have items with the tendencies of the "main series" and the more routine series. Interestingly the group of fourteen shield portraits of divinities from Aquileia also has been noted to show a high quality group as opposed to a lesser group. ${ }^{50}$ Thus, the careful examination presented here of the lost shield portraits presents us the third case of a group, connected thematically and in general location, of shield portraits that have a distinct stylistic division.

Considering the three areas defined at the outset of this paper - the technical details of the carving and choice of model (style), the structural specifications (manufacture), and the subject matter (iconography and theme), we may note again that the subject matter and specifications of manufacture pertain most closely to the patron who dictated the context; the patron of the Evangelical School and Atrium house had similar desires and similar spaces to fill. The choice of models pertains probably to a director in a workshop. The carving of specific de-

\footnotetext{
${ }^{49}$ Smith 1990, 131-132. Lippold above at n. 7.

${ }^{50}$ Sperti 2004, 174-175.
} 
tails reflects the preferences of a single sculptor. The workshops in question had clearly similar models but the sculptors were not always the same. ${ }^{51}$

\section{Manufacture, style, and iconography of Gaudin shield portraits in broader context of Roman Empire}

The evolution of the shield portrait and its use for special honorands, notably rulers and divinities, has been well-established, and there is ample extant testimony of portraits in shields in various media to demonstrate that it was commonly used during the Empire. Here it is sufficient, as a reminder, to quote Pliny the Elder. In book 35 of the Natural History, written in the first century A.D, Pliny reminds us of the long Roman experience with the genre of shield portraits.

III. But the first person to institute the custom of privately dedicating the shields with portraits in a temple or public place, I find, was Appius Claudius, the consul with Publius Servilius in the 259th year of the city. He set up his ancestors in the shrine of the Goddess of War, and desired them to be in full view on an elevated spot, and the inscriptions stating their honours to be read. This is a seemly device, especially if miniature likenesses of a swarm of children at the sides display a sort of brood of nestlings; shields of this description everybody views with pleasure and approval.

IV. After him Marcus Aemilius, Quintus Lutatius's colleague in the consulship, set up portrait-shields not only in the Basilica Aemilia but also in his own home, and in doing this he was following a truly warlike example; for the shields which contained the likenesses resembled those employed in the fighting at Troy; and this indeed gave them their name of clupei, which is not derived from the word meaning 'to be celebrated,' as the misguided ingenuity of scholars has made out.

The mention of the Basilica Aemilia is interesting because it was a large public space and would have entailed a significant series of shields. A coin dated to the 70s B.C. appears to show these shields strung along the architrave of the lower level; one above each column and one between each column. ${ }^{52}$

There are four specific published instances of marble shield portraits that have an association with the shield portraits of Aphrodisias. These include a set of possibly as many as fourteen shield portraits of divinities from Aquileia, twelve shield portraits of divinities from Chiragan, six of philosphers from Rome, and the four of church leaders from Istanbul.

The numerous shield portraits ascribed to the city of Aquileia and identified by Sperti include a: Zeus; Hephaistos; Mars; Roma/Virtus/Minerva; Mercury; Dioscurus/Attis; a goddess with a fillet; a goddess with a band; Mars; Minerva; Isis; Jupiter; and a fragment. ${ }^{53}$ The best of the Aquileia shield portraits - and here I note again, they vary in the quality of the carving - have stylistic similarities to those from Aphrodisias; they have been cautiously said to be

\footnotetext{
${ }^{51}$ Squarciapino suggested similarly with regard to the shield portrait of the boy with the bulla (3) and the goddess (4). Squarciapino 1943, 78, "più che a opera d'età differenti, fa pensare a due distinti autori."

${ }^{52}$ Winkes 1969, Rom 4.

${ }^{53}$ Sperti 2004.
} 
like sculpture produced in Asia Minor in the sphere of the "School of Aphrodisias". 54 As those from Aphrodisias, they are made in one piece with their rectangular backgrounds but the shield itself is undulating with a complex profile. They are however significantly larger; the Zeus measures $100 \times 97 \mathrm{~cm}$ and the Roma/Virtus/Minerva $102 \times 82 \mathrm{~cm} .{ }^{55}$ It is noteworthy that the group depicts only divinities. Although Sperti dismisses the possibility that they were once located in the area of the Forum where the headless Minerva was found, they represent traditional Roman values of divinity and authority. In any case, whatever their setting, the models flexibly followed standard traditional models or types but included some unexpected details, and in this, they differ from the Aphrodisian works. For example, "Roma/Virtus/" wears long, loose, hair; a helmet with a wreath; and a decorated baldric; the Minerva has an unusual decoration crest on the helmet; the Mars is a youth in a Roman cuirass; and the Jupiter (now in Copenhagen) wears a "corona civica." A shield portrait of Ares, now in Dresden and said to have been purchased in Rome, ${ }^{56}$ plausibly relates to this group. It shows a bearded Mars in a costume (bare chest, baldric, and chlamys) that is usually appropriate for a young Mars. This unusual choice is symmetrical to that of the Aquileia shield portrait of Mars where a young, beardless Mars, is combined with the iconography of a mature, bearded Mars; that is, Roman armour is combined with a young, clean-shaven face.

The late-antique villa at Chiragan presents us with a similar set of shield portraits that again have stylistic affinities to works from Aphrodisias and are even generally accepted to have been made by itinerant sculptors from Aphrodisias, probably in the fourth century. ${ }^{57}$ At Chiragan, as at Aquileia, the numerous shield portraits, at least twelve, depict divinities which are listed by Bergmann as Athena, Hephaistos, Asklepios, Hygeia, a goddess with a mural crown (Kybele?), a young male with long locks and a Phrygian cap (Attis?), three goddesses with crowns, and two gods whose heads are missing, plus a headless bust in a chiton and himation. ${ }^{58}$ They are finely carved, large, and made of local Sainte-Beat marble; the average diameter is ca. $90 \mathrm{~cm}^{59}$ The shields are not, however, attached to flat rectangular backgrounds.

Only in Rome is there an extant and comparable series of shield portraits of cultural heroes. These shield portraits include Menander (the Marbury Menander), Demosthenes, Socrates, the Bornova-Heidelberg, Aeschines?, and a headless example. ${ }^{60}$ The Menander and the Bornova-Heidelberg portraits have both been already mentioned for the associations to the similar portraits in the Evangelical School group. The Rome six appear to have been one late-

\footnotetext{
${ }^{54}$ Sperti 2004, 151, in the abstract notes: "La maggior parte di queste sculture va ascritta a maestranze microasiastiche che operano nell'ambito della cossidetta Scuola di Afrodisia in un raffinato stile classicistico." For specific comparison to the Atrium House shield portraits, Sperti 2004, 154, the drilling and bridges in the hair of Zeus is compared to the Alexander the Great from the Atrium House.

${ }^{55}$ Fogolari 1955, 143 for dimensions of Jupiter, 152 for dimensions of Roma. The "cornice" is given respectively at 75 and $70 \mathrm{~cm}$.

${ }^{56}$ Winkes 1969, 158 (catalogue entry) 79 (identifies it as Mars). It is W: $49.5 \mathrm{~cm}$ and has drilled eyes.

${ }^{57}$ Esperandieu II, no. 892, lists 11, plus nos. 901 and 918. Bergmann 1999, 33. Most recently Attanasio et al. 2016, 169171 repeat this.

${ }^{58}$ Bergmann 1999, 33 suggests that the headless bust wearing the chiton and himation might be a portrait, in particular of a philosopher.

${ }^{59}$ Attanasio et al. 2016, 169-171 and 183-184.

${ }^{60}$ Lenaghan in Smith, Ward-Perkins, 2016, 264-265, fig. 22.3; LSA 2511, 2287, 2440, 2441, 2109. The headless example, formerly in the Cook collection, is now at the Indiana Museum.
} 
antique commission because of the uniformity of their subject and because all consist only of a circular shield (not against a rectangular background); all have a unfurled scroll against the empty space around the head, and are of similar size; the shield has an approximate diameter of $50 \mathrm{~cm} .{ }^{61}$ The date is deduced by the style. They were intended to be labelled - the name Demosthenes appears on an unfurled scroll within the shield and Menander is labelled on the shield rim in the same way the Atrium House portraits are labelled - so strict typological adherence to models was not necessary. They nonetheless do loosely follow classical types and seem in their choice of dress (bare-chested for the Bornova-Heidelberg philospher, barechested with himation for Socrates, Aeschines?, and Demosthenes, and himation and chiton for Menander) to reflect traditional assumptions about the historic eras of the individuals.

Finally, four shield portraits that show bearded men holding books adorned with an engraved cross from Istanbul relate to those found at Aphrodisias. ${ }^{62}$ Although bigger than the Aphrodisian examples (W: $65 \mathrm{~cm}$ ), they are worked together with their backgrounds and feature a shield with a simple profile. ${ }^{63}$ The eyes of the only preserved head resemble those of the Old Philosopher; ${ }^{64}$ the folds around the right arm and the neckline of one of the Istanbul fragments recall those of a fragment from the Atrium House (FIG. 9b). ${ }^{65}$ The hairstyle of the only extant portrait belongs securely to the later fourth or fifth century $\mathrm{AD}{ }^{66}{ }^{6}$ These shield portraits show the effectiveness of the genre (readily transferred from the Basilica Aemilia into the sphere of the Christian church).

This quick survey of relevant shield portraits outside Aphrodisias allows for some simple conclusions. These shield portraits were produced in groups for ostentatious buildings in the late Roman period. Stylistic analysis shows that either sculptors from the same workshop were creating these works in different parts of the Empire or that contemporary sculptors employed a similar style, a period style. The structural specifications vary, and this is surely the result of local constraints. For example, at Chiragan, the lack of a rectangular frame around a shield that was already $90 \mathrm{~cm}$ in diameter was probably to keep the size of the blocks at reasonable cost and to keep final object at manageable weight. The smaller size of the Rome group and its lack of frame should be imagined to be in keeping with a spatially more modest context.

The subject matter depended on the commissioner. It is interesting that the two large western groups display the popular divinities of the pagan Roman Empire. How similar were the patrons and the contexts? The shield portraits of cultural heroes have been well been associated with libraries. Pliny the Elder's discussion of shield portraits, cited above, suggestively follows his paragraph on the inspirational portraits in libraries where Homer is particularly mentioned. ${ }^{67}$ In the definitive publication of the Atrium House shield portraits, Smith demonstrated convincingly the context for these shield portraits. The elements of the building

\footnotetext{
${ }^{61}$ The Heidelberg example is about $7 \mathrm{~cm}$ smaller.

${ }^{62}$ LSA 2416, 2417, 2418, 2419: Mendel 1912-1914, nos. 661, 662, 663, 664; Firatli 1990, 19-20, nos. 36, 37, 38, 39, pls. 16-17.

${ }^{63}$ Mendel 1912-1914, no. 661, 444 says the background was octagonal. In photographic documentation this does not seem to be the case.

${ }^{64}$ LSA 2416: Mendel 1912-1914, no. 661; Frratlı 1990, no. 36, pl. 16.

${ }^{65}$ LSA 2419: Mendel 1912-1914, no. 664; Firatl1 1990, no. 36, pl. 16, and Aphrodisias, inv. 83-156.

${ }^{66}$ LSA 2416: Mendel 1912-1914, no. 661; Frratl1 1990, no. 36, pl. 16.

${ }^{67}$ Winkes 1969, 64-65.
} 
and iconography indicate a "private mansion, library, and place of higher learning" and the School of Asklepiodotos at Aphrodisias provides a compelling possibility. ${ }^{68}$

The thematic adherence of the Gaudin Izmir group of seven, the Atrium House group of nine, and the Rome group of six provides the correct context into which should be inserted a head of Plato sold at Christies NY in 2011. There is little doubt that these shield portraits were produced for serial display in places of academic pretension, and the head in question probably come from a late Roman series of shield portraits of cultural figures. The style, - the plain version of the well-known model and the emphatic eyes - make it at earliest late third century. It is of the correct scale and comparable in style to some of the Aphrodisian examples. It recalls the Evangelical School Pindar (3, FIG. 4).

8. Head of Plato. From shield portrait? Later third century to fifth century AD. (FIGS. 16-19) Bibliography: Christies Lot 200 Sale 2450 Antiquities New York 9 June 2011; LSA 2537 (Lenaghan).

H: $25.4 \mathrm{~cm}$.

The head is preserved from the top of the head to the middle of the neck; the lower part of the beard is missing. It shows a man with a long beard and long moustache. The head turns to its right, revealing more of the left side of the head to the viewer. It is a simple but recognizable version of the portrait of Plato.

The back of the head was once attached to an object, probably the background of a shield portrait. At the back there is a large area of uneven stone, the outline of which rises to the middle of the back of the head. Above and around it the hair is only roughly worked. Around its right side (behind the right ear), the points or ends of drill channels can be seen. Although this might represent the remains of a large support or brace at the back of the neck of a statue (a neck pillar), it would be unusual both because it continues to the height of the ears and because on the right side of the head (which was turned away from the viewer) the area round the broken area is significantly less well worked. Both of these details are more readily comprehensible if one imagines that the head was attached completely at the back of the neck and above the neck at the back of the head to a backdrop. This is the kind of attachment one sees in the Menander formerly at the Evangelical School (1, FIG. 1) and in the head of the Young Pupil at Aphrodisias. ${ }^{69}$ The Bornova shield portrait, which is broken from its background at the neck (7, FIG. 14), provides good visual comparanda for the tall curving outline of the break and the lack of detail or finish in the hair around it.

Style alone provides an indication of date; the eye markings have a terminus post quem of the later third century. The irises are almost complete engraved circles. The pupils are deeply drilled out in a tight round crescent shape and are located immediately under a heavy upper eyelid. The hair is flatly rendered which makes the pattern of locks seem more simplified than they are. ${ }^{70}$ It seems comparable to the rendering of the hair of both the Evangelical

\footnotetext{
${ }^{68}$ Smith $1990,130$.

${ }^{69}$ Smith 1990, pl. 14.3.

${ }^{70}$ Richter 1965, II 164-170. This version perhaps best resembles the head in Cambridge, Richter 167, no. 16, figs. 945 947.
} 
School Pindar and the Menander. The face is not carefully articulated which gives intensity to the deeply drilled eyes, and again recalls the frozen, air-brushed quality of the others.

So we may now return to the lost portraits from the Evangelical School with a reinforced emphasis on the importance of subject/patron. Style is suggestive and elusive; building specifications depend often on practicalities; but the subject is a unifying element in a commission. It, to be sure combined with style, allows us even to consider a head of Plato on the art market in our discussion of Aphrodisian shield portraits.

\section{The context at Aphrodisias}

The two groups of shield portraits at Aphrodisias, those of the Evangelical School and those excavated at the Atrium House, have always been considered two distinct groups. Stylistically, however, both groups are not entirely uniform, and both groups show some tendencies of the other. Both groups also use standard models. In terms of specifications of manufacture, the shields and the frames of both groups are similar. Some of the Evangelical School items are smaller but others and the Bornova example are not. Their general appearance as well as their cost and weight in marble would presumably have been much the same. The subject matter is also generally the same; the Evangelical School includes two divinities which are lacking at the Atrium House. The Evangelical School includes two boys of particularly young age, one perhaps an infant and the other a child. Both appear as marked as involved in cultic or ceremonial functions.

This means in play among the two groups are: two different hands, probably in the same workshop and possibly at slightly different chronological moments; similar budgets and similar physical locations; and similar patrons with similar wall spaces to fill. Thus, it is possible that two different patrons in two different houses commissioned two different sets of shield portraits of cultural heroes and family members. One could imagine that more than one man of culture at Aphrodisias had a library area in his home and was involved in the maintenance of traditional Hellenic culture. Here one might add that in general perhaps more of the extant $3^{\text {rd }}$ to $5^{\text {th }}$ c. portrait heads of philosophers may have come from shield portraits than we have previously considered and that this was more fashionable than the clear series at Rome and Aphrodisias would indicate.

But because it does not seem to be the case that all those of one style and manufacture are exclusively from one context and all those of another style and manufacture are from another context, it is worth considering the possibility that all the shield portraits from Aphrodisias of cultural heroes might have come from one context. In fact, the fragments of shield portraits in the depots of Aphrodisias attest at least five other shield portraits in the area of the Atrium House, and tantalizingly offer us the possibility that some may have joined the now lost objects from Aphrodisias. ${ }^{71}$ Also, the Atrium House had a connection to traditional cults. It has a monumental doorway that opens to the steps of the Temple of the Sebasteion complex. ${ }^{72}$ And a large bust showing a man holding a statuette of the Aphrodite of Aphrodisias was excavated in the peristyle court. ${ }^{73}$

\footnotetext{
${ }^{71}$ The four fragments, mentioned above, which all preserve a right shoulder and so do not join with each other or the nine presented by Smith, are inv. 69-371, 79-173, 82-134, 83-156, and 87-416.

${ }^{72}$ Lockey 2016, fig. 15.1 no. 24.

${ }^{73}$ Smith et al. 2006, 238-239, no. 127, pl. 95.
} 
There are two considerations that may support this possibility. First, the peristyle court of the Atrium House at Aphrodisias has not been completely excavated. It nonetheless preserves six intercolumniations on its west side and three of at least another six on its north side. ${ }^{74}$ If the shield portraits were located on the back wall of only three sides of this portico, there would have easily been room enough for at least eighteen shield portraits. Two portraits of the same individual may even have been desired; the herm busts at the late antique villa at Welschbillig show two herms of most individuals. ${ }^{75}$ Second, the Aquileia examples would support the reading that a large commission of technically difficult opera might require different sculptors and result in objects of diverse quality. This understanding sits more easily when one considers that these objects are integral to an architectural program; they must have been set within the revetment in a timely fashion and they were viewed from below. The one entails pressure of meeting deadlines, and the other permits for some sub-par details.

Alternatively, one might combine both the idea of two commissions and one context. It might be imagined that an original fourth-century space included a certain number of such shield portraits. The House was then refurbished in the fifth century, and new portraits might have been added. This solution would allow for the more traditional interpretation of a stylistic development through time and satisfy the idea of a workshop producing in the same tradition for a similar context and patron.

\section{Conclusion}

This paper has endeavoured to define precisely the characteristics of the shield portraits brought from Aphrodisias to Izmir by Paul Gaudin. The evidence is scant but does allow for some concrete conclusions and promising hypotheses. Although most of these points may seem obvious to scholars, they have never been clearly expressed.

The Evangelical School shield portraits were created in the fourth or even fifth century in a workshop at Aphrodisias where traditional models were well-known and carving ranged from competent to excellent. They were made as a series to fill similar spaces and for a patron who had literary pretensions. Both the Bornova shield portrait and a head recently on the art market may be related, the one with highest probability and the other with some probability. In all of these details of style, manufacture, and subject, the lost portraits from the Evangelical School overlap with the shield portraits found at the Atrium House which probably also date to the later fourth or fifth century AD. These two groups do constitute ca. twenty shield portraits definitively made at Aphrodisias in Late Antiquity and so would show the Aphrodisian workshops of that moment well-equipped to produce images of cultural heroes and this sort of shield portrait. A glance at the broader picture of shield portraits in the Roman world shows that several other series of such portraits in marble are preserved from Late Antiquity and that the groups generally tended to be large commissions made at one moment. These series represent a time-honoured tradition and one whose late-antique expression in marble may relate to the city of Aphrodisias. Such an assumed relationship is tempting and indeed possibly true but methodologically based only on points of style and the incomplete record of preservation. Perhaps most usefully, we can take away from this exercise that shield

\footnotetext{
${ }^{74}$ Lockey 2016, 252 imagines twelve shield portraits because he considers only the east and west sides of the portico.

${ }^{75}$ Pairs at Welschbillig: see for example, Wrede 1972, nos. 31 and 39, nos. 14 and 24, nos. 35 and 41, nos. 91 and 92.
} 
portraits are set in architecture and therefore are subject to less change, bigger commissions, and greater tolerance for disparate details. Also that the different subjects in the late-antique marble shield portraits indicates the range of the patrons; portraits of contemporaries, cultural heroes, divinities, and church fathers were all possible and were made by marble sculptors working in similar modes.

Table 1 - Concordance of nine shield portraits from the Atrium House at Aphrodisias.

\begin{tabular}{|l|l|l|l|l|l|l|}
\hline & NAME & INV & Smith JRS 1990 & Smith Aph Papers 2 & Width & "Group" \\
\hline AH 1 & $\begin{array}{l}\text { Apollonios } \\
\text { (headless) }\end{array}$ & $81-114$ & No. 7, 141-144, pl. 11 & No. 7, 151-153, fig. 8 & $53.5 \mathrm{~cm}$ & Main series \\
\hline AH 2 & Young Pupil & $81-137$ & No. 9, 146-147, pl. 11 & No. 9, 155, fig. 10 & $53.5 \mathrm{~cm}$ & other \\
\hline AH 3 & Pindar & $81-115$ & No. 1, 132-135, pls. 6-7 & No. 1, 146-148, pls. 6-7 & $54 \mathrm{~cm}$ & Main series \\
\hline AH 4 & Alexander & $81-101$ & No. 2, 135-138, pls. 8-9 & No. 2, 148, fig. 3 & $54 \mathrm{~cm}$ & Main series \\
\hline AH 5 & $\begin{array}{l}\text { Alcibiades } \\
\text { (headless) }\end{array}$ & $81-136$ & No. 3, 138-139, pl. 9 & No. 3, 148-150, fig. 4 & $55 \mathrm{~cm}$ & Main series \\
\hline AH 6 & Pythagoras & $\begin{array}{l}81-135 \\
68-486\end{array}$ & $\begin{array}{l}\text { No. 6, 141, pl. 11 plus } \\
\text { Addendum }\end{array}$ & No. 6, 151-153, fig. 7 & $56 \mathrm{~cm}$ & Main series \\
\hline AH 7 & Old Philosopher & $81-112$ & No. 8, 144-146, pls. 12-13 & No. 8, 153-155, fig. 9 & $58.5 \mathrm{~cm}$ & Main series \\
\hline AH 8 & Socrates & $81-103$ & No. 4, 139-140, pl. 10 & No. 4, 150-151, fig. 5 & $64 \mathrm{~cm}$ & Other \\
\hline AH9 & Aristotle & & No. 5, 140-141, pl. 10 & No. 5, 150-151, fig. 6 & & $\begin{array}{l}\text { Frame in } \\
\text { black marble }\end{array}$ \\
\hline
\end{tabular}

Julia Lenaghan

Oxford University

julia.lenaghan@classics.ox.ac.uk 


\section{BIBLIOGRAPHY}

Almagro Gorbea, M. 2000: El disco de Teodosio, Madrid: Real Academia de la Historia.

Arndt, P., Lippold, G. (eds.) 1929: Photograpische Einzelaufnahmen antiker Sculpturen zur Vorbereitung eines Corpus Statuarum, Series IX, Munich.

Attanasio, D., Bruno, M., Proschaska, W. 2016: "The Marbles of the Roman Villa of Chiragan at MatresTolosane (Gallia Nabonensis)", AA, 159-200.

Balty, J. 1982: "Paedagogiani - pages de Rome à Byzance", in L. Hadermann-Misguich, G. Raepsaet (eds.), Rayonnement grec. Hommages à Charles Delvoye, Brussels, 299-312.

Bergemann, J. 1991: "Pindar", AM 106, 155-189.

Bergmann, M. 1999: Chiragan, Aphrodisias, Konstantinopel - Zur mythologischen Skulptur der Spätantike, Wiesbaden.

Bieber, M. 1977: Ancient Copies: Contributions to the History of Greek and Roman Art, New York.

Bruns, G. 1935: Der Obelisk und seine Basis auf dem Hippodrom zu Konstantinopel, Istanbul.

Campbell, S. 1991: The Mosaics of Aphrodisias in Caria, Toronto.

Danguillier, C. 2001: Typologische Untersuchungen zur Dichter- und Denkerikonographie in römischen Darstellungen von der mittleren Kaiserzeit bis in die Spätantike (BAR International Series 977), Oxford.

Firatl1, N. 1990: La sculpture Byzantine figurée au Musée Archéologique d'Istanbul, Paris.

Fittschen, K. 1991: "Zur Rekonstruktion griechischer Dichterstatuen. 1. Teil: Die Statue des Menander", AM 106, 243-79.

Fogolari, G. 1955: "Medaglioni aquileiesi con busti di divinità”, Studi aquileiesi offerti a Giovanni Brusin, Aquileia, 141-167.

Goette, H-R. 1989: "Römische Kinderbildnisse mit Jugend-Locken”, AM 104, 203-217.

Goette, H-R. 1986: "Die Bulla”, BJb 186, 133-164.

Helbig 4. 1966: Führer durch die öffentlichen Sammlungen klassischer Alterthümer in Rom. II. Die Städtischen Sammlungen: Kapitolinische Museen und Museo Barracco. Die Staatlichen Sammlungen: Ara Pacis, Galleria Borghese, Galleria Spada, Museo Pigorini, Antiquitaten auf Forum und Palatin, Tübingen.

Krumeich, K. 2005/2006: "Der Knabe mit goldener bulla. Ein ägyptisches Nischengrabrelief aus der Zeit nach der constitutio Antoniniana in Dr AbeggStiftung, Riggisberg", JbAC 48/49, 128-153.

Lenaghan, J. 2018: "Reidentifying two late antique heads from Aphrodisias as Menander and Homer(?)", JRA 31, 458-473.

Lippold, G. 1956: Die Sculpturen des Vatikanischen Museums III, Berlin.

Lippold, G. 1918: "Ikonographische Probleme", $R M$ 33, 1-30.

LSA Last Statues of Antiquity website at http://laststatues.classics.ox.ac.uk.

Lockey, I. 2016: "The Atrium House: the archaeology of a late-antique residence", in R.R.R. Smith et al. (eds.), Aphrodisias Papers 5: Excavation and Research at Aphrodisias, 2006-2012 (JRA, Supplement 103), Portsmouth, RI, 243-254.

Lucchesi-Palli, E. 1995: "Die römische bulla und ihre Verbreitung in Ägypten", in Divitiae Aegypti. Koptologische und verwandte Studien zu Ehren von Martin Krause, Wiesbaden, 206-213.

Mendel, G. 1912-1914: Musées impériaux ottomans. Catalogue des sculptures greques, romaines et byzantines I-III, Istanbul.

Moltesen, M. 2002: Catalogue. Imperial Rome II Statues. Ny Carlsberg Glyptotek, Copenhagen.

Richter, G.M.A. 1965 I-III: The Portraits of the Greeks, London.

Richter, G.M.A. 1962: "The Menander Medallions", AM 77, 250-254.

Sande, S. 2015: "The "Barbarian princes", in the Ara Pacis procession and the origin and development of the so-called Camillus coiffure", AAArtHist 28, 7-46.

Sande, S. 1982: "Bemerkungen zum sogenannten Pausianias-Portät", AAArtHist 2, 55-75.

Smith, R.R.R. 1996: "Archaeological research at Aphrodisias, 1989-1992: A. The campaigns of 1989 and 1990, B. The campaigns of 1991 and 1992", in C. Roueché, R.R.R. Smith (eds.), Aphrodisias Papers 3: the setting and quarries, mythological and other sculptural decoration, architectural development, Portico of Tiberius, and Tetrapylon (JRA Supplement 20), Ann Arbor, MI, 10-72.

Smith, R.R.R. 1995: “A New Shield Portrait in Izmir”, RM 102, 332-335, pls. 77-78.

Smith, R.R.R. 1993: The Monument of C. Iulius Zoilos, Mainz am Rhein. 
Smith, R.R.R. 1991a: "Late Roman philosophers", in R.R.R. Smith, K.T. Erim (eds.), Aphrodisias Papers 2: the theatre, a sculptor's workshop, philosophers, and coin-types (JRA Supplement 2), Ann Arbor, MI, 144-158.

Smith, R.R.R. 1991b: “A new portrait of Pythagoras", in R.R.R. Smith, K.T. Erim (eds.), Aphrodisias Papers 2: the theatre, a sculptor's workshop, philosophers, and coin-types (JRA Supplement 2), Ann Arbor, MI, 159-167.

Smith, R.R.R. 1990: "Late Roman Philosopher Portraits from Aphrodisias", JRS 80, 127-155.

Smith, R.R.R., Dillon, S., Hallett, C.H., Lenaghan, J., Van Voorhis, J. 2006: Aphrodisias II. Roman Portrait Statuary from Aphrodisias, Mainz am Rhein.

Smith, R.R.R., Ward-Perkins, B. 2016: The Last Statues of Antiquity, Oxford.
Sperti, L. 2004: "Scultura microasiatica nella cisalpine tardoantica. I tondi aquilensi con busti di divinità", Eidola 1, 151-193.

Squarciapino, M. 1943: La Scuola di Afrodisia, Rome. Studniczka, F. 1918: Das Bildnis Menanders, Leipzig.

Vermeule, C.C.C. 1965: "A Greek Theme and Its Survivals: The Ruler's Shield (Tondo Image) in Tomb and Temple", PAPhS 109. 6 (Dec. 10, 1965), 361-397.

Winkes, R. 1969: Clipeata Imago. Studien zu einer römischen Bildnisform, Bonn.

Wrede, H. 1972: Die spätantike Hermengalerie von Welschbillig: Untersuchung zur Kunsttradition im 4. Jahrhundert n. Chr. und zur allgemeinen Bedeutung des antiken Hermenmals, Berlin. 


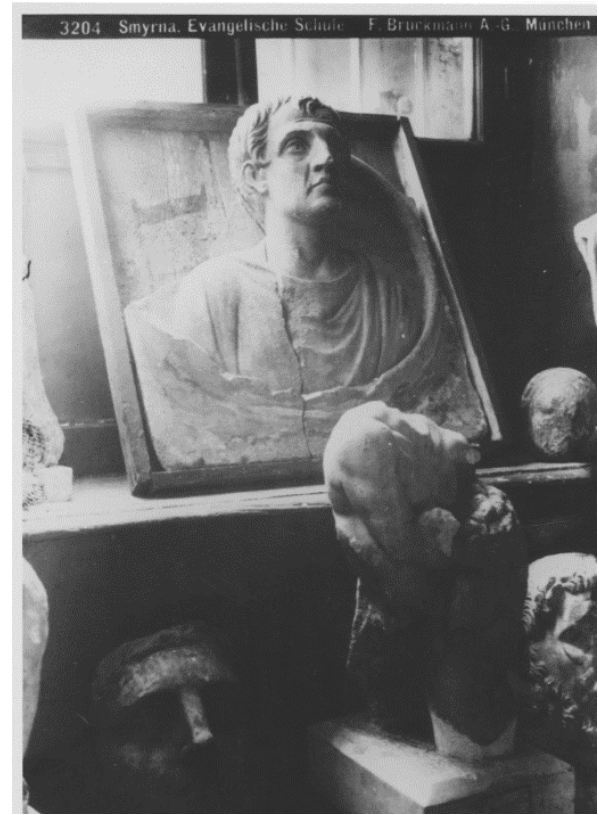

FIG. 1 - Shield portrait of Menander, formerly Evangelical School, seen in 3/4 view. EA 3204.

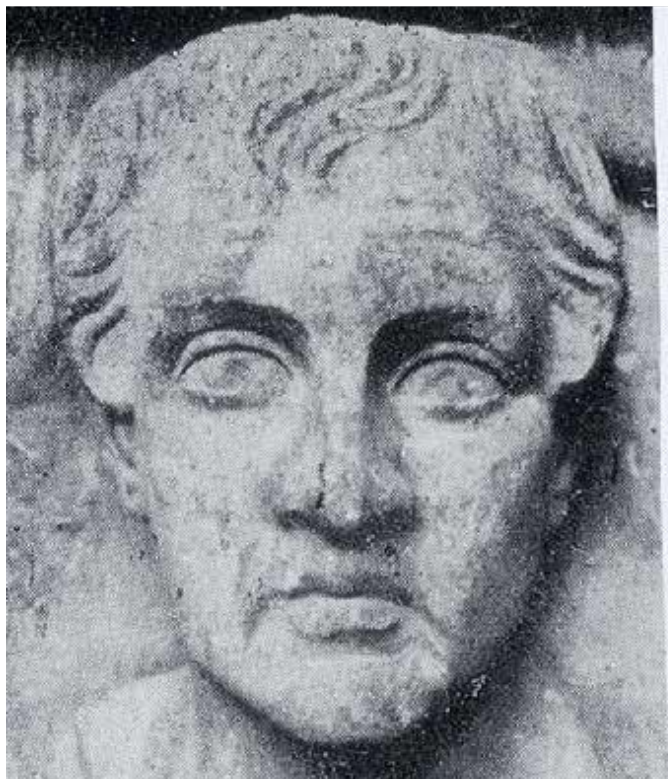

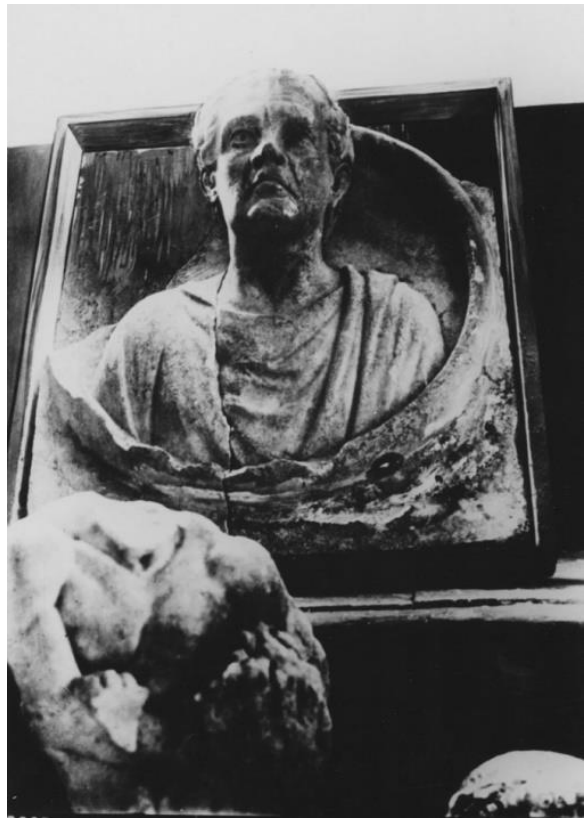

FIG. 2 - Shield portrait of Menanderr, formerly Izmir, seen from below. EA 3205 .

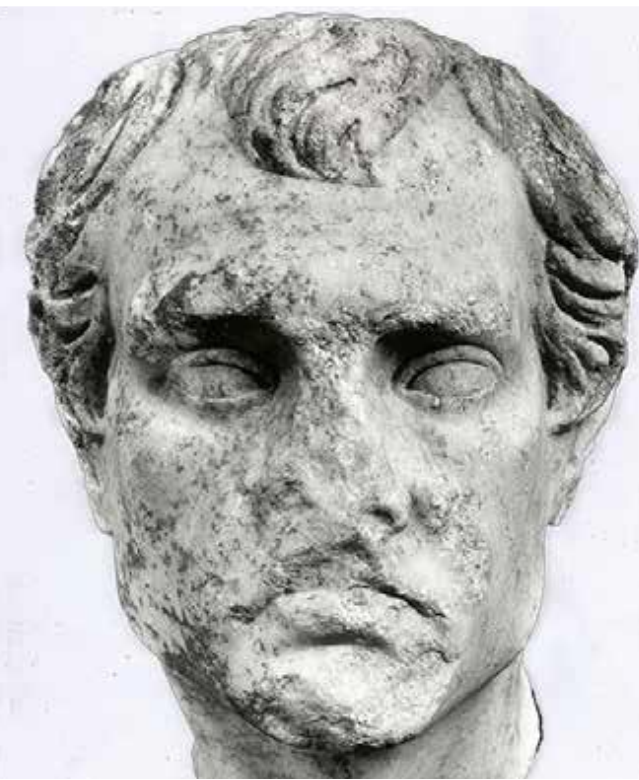

FIG. 3 - Head of Menander from Izmir shield portrait (a) and portrait head of Menander? from Atrium House, Aphrodisias. After Studniczka, pl. 6.5 and courtesy of the New York University Excavations at Aphrodisias. 


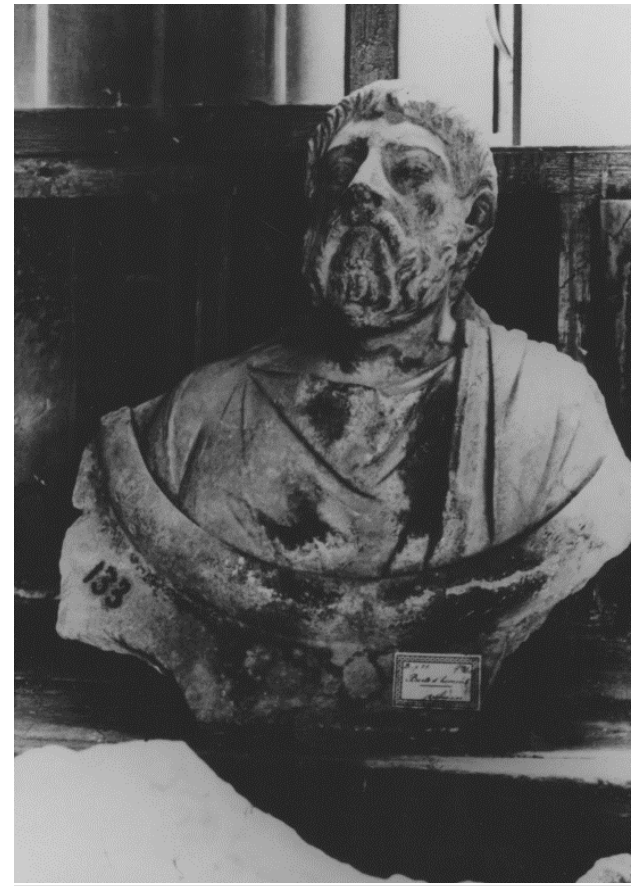

FIG. 4 - Shield portrait of Pindar, formerly Evangelical School. EA 3206.

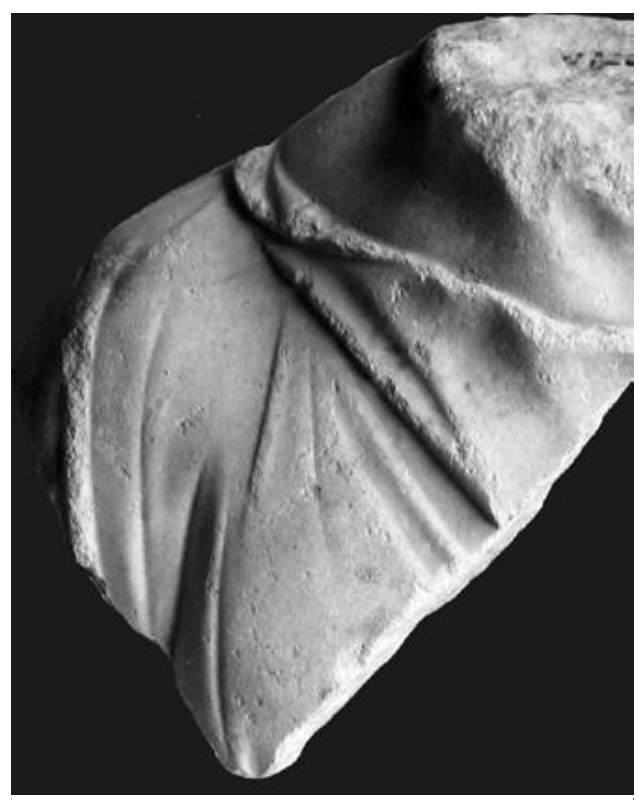

FIG. 6 - Fragmentary shield portrait from Aphrodisias, inv. 69-371A. Courtesy of the New York University Excavations at Aphrodisias.

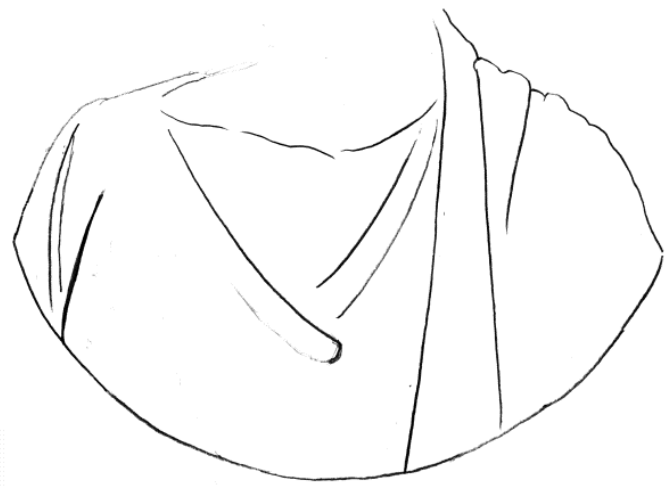

FIG. 5 - Schematic drawing to illustrate three common fold patterns in the Menander and Pindar shield portraits.

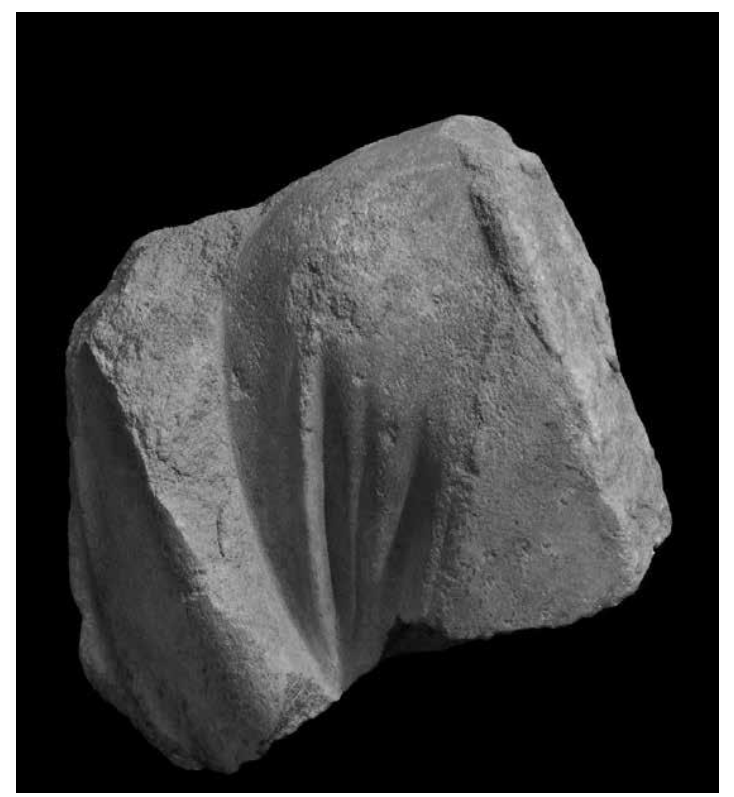

FIG. 7 - Fragmentary shield portrait from Aphrodisias, inv. 87-416. Courtesy of the New York University Excavations at Aphrodisias. 


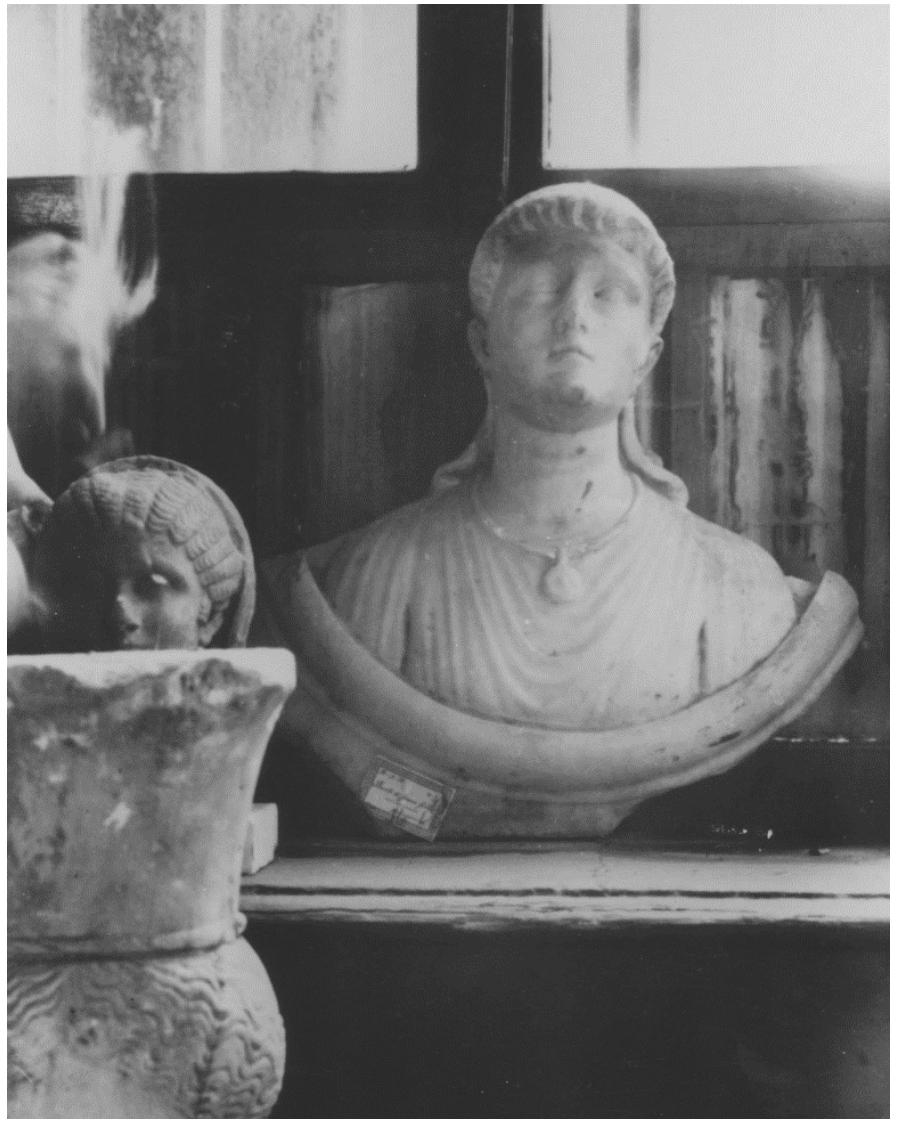

FIG. 8 - Shield portrait of boy with bulla, formerly Evangelical School. EA 3207.

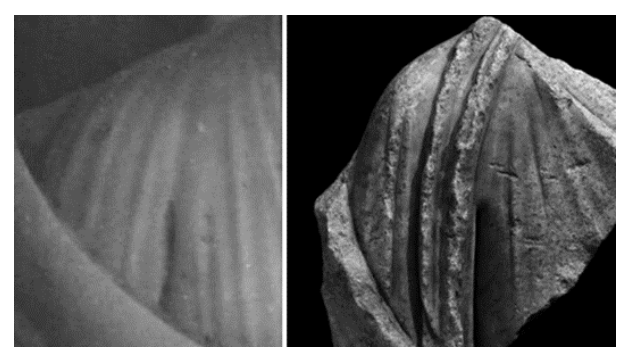

FIG. 9 - Detail of right shoulder of shield portrait of boy with bulla, formerly Izmir (a) and right shoulder of fragmentary shield bust, inv. 83-156, Aphrodisias (b). Detail of EA 3207 and courtesy of the New York University Excavations at Aphrodisias.

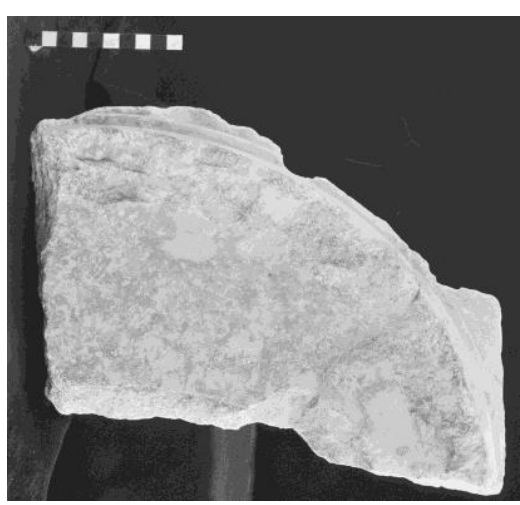

FIG. 10 - Fragment showing area of shield behind left shoulder and portion of frame, inv. 82-91. Courtesy of the New York University Excavations at Aphrodisias. 


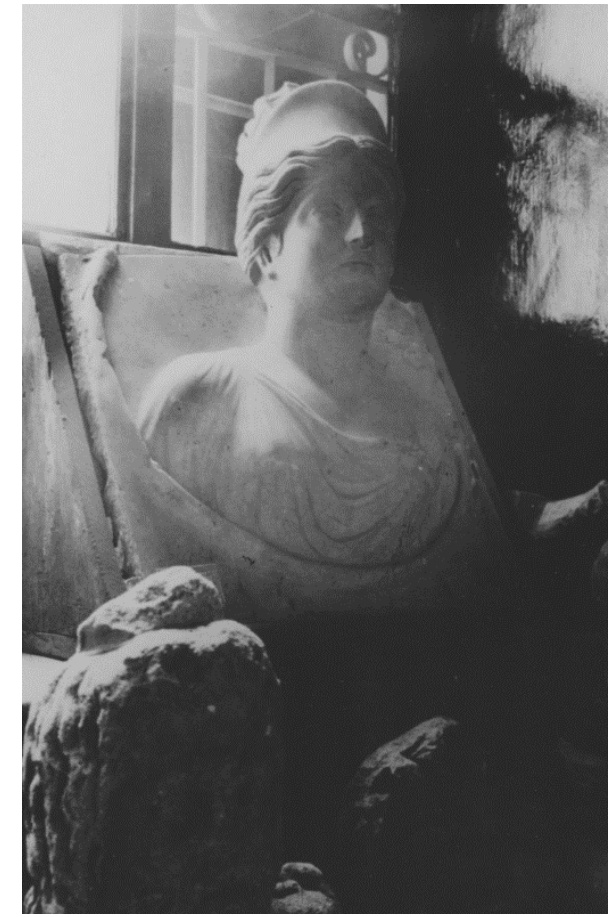

FIG. 11 - Shield portrait of goddess, formerly Evangelical School. EA 3208.

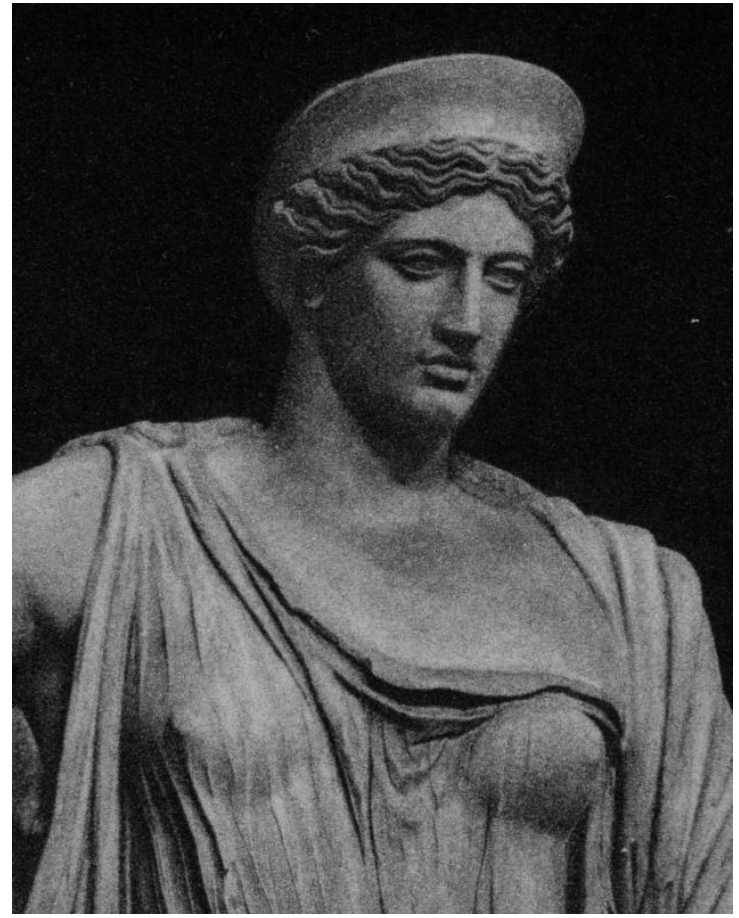

FIG. 12 - Upper body of Hera Barberini, Vatican Museums. After Lippold 1956.
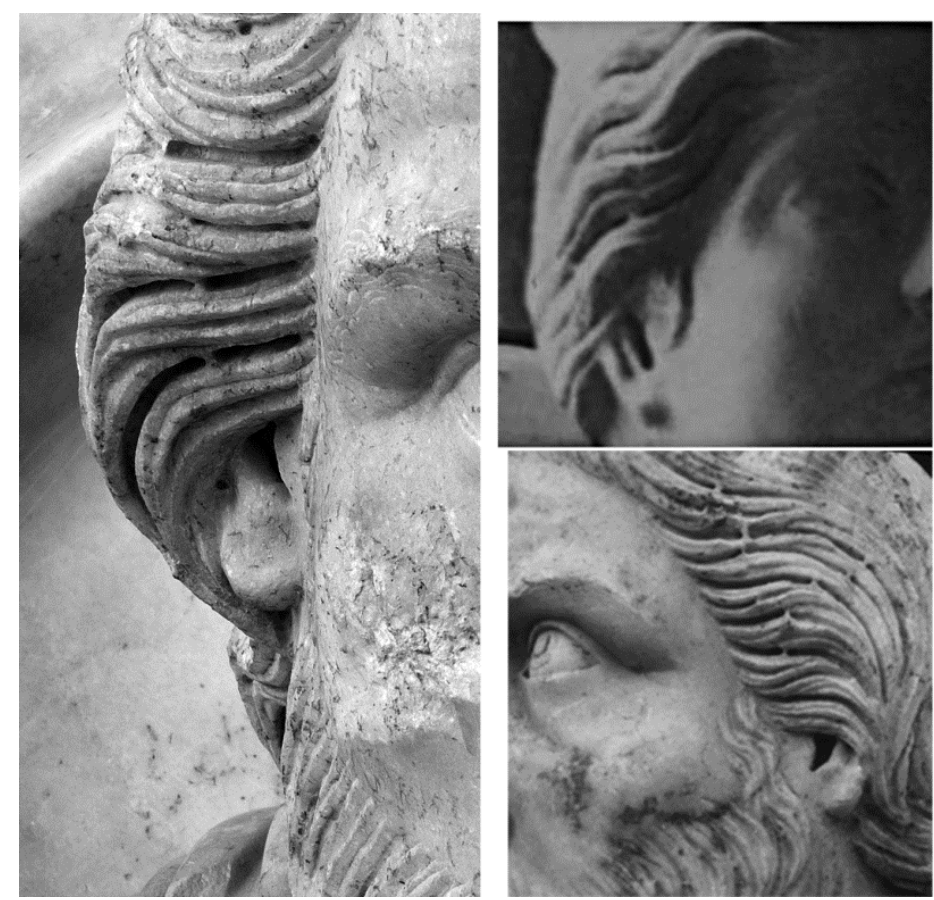

FIG. 13 - Detail of right temple of goddess, formerly Evangelical School (a) and left temple of Old Philosopher, Aphrodisias. Detail of EA 3208 and courtesy of the New York University Excavations at Aphrodisias. 


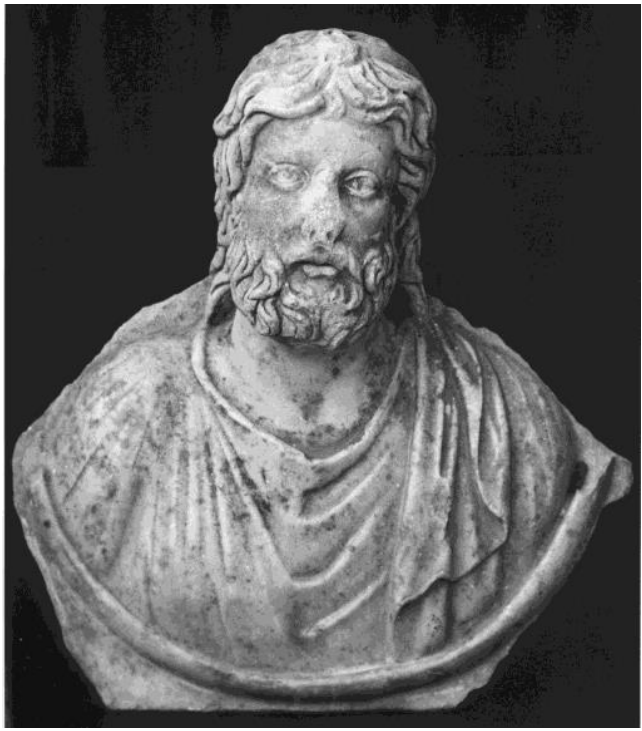

FIG. 14 - Shield portrait of Bornova-Heidelberg type from Bornova. Izmir Archaeological Museum.

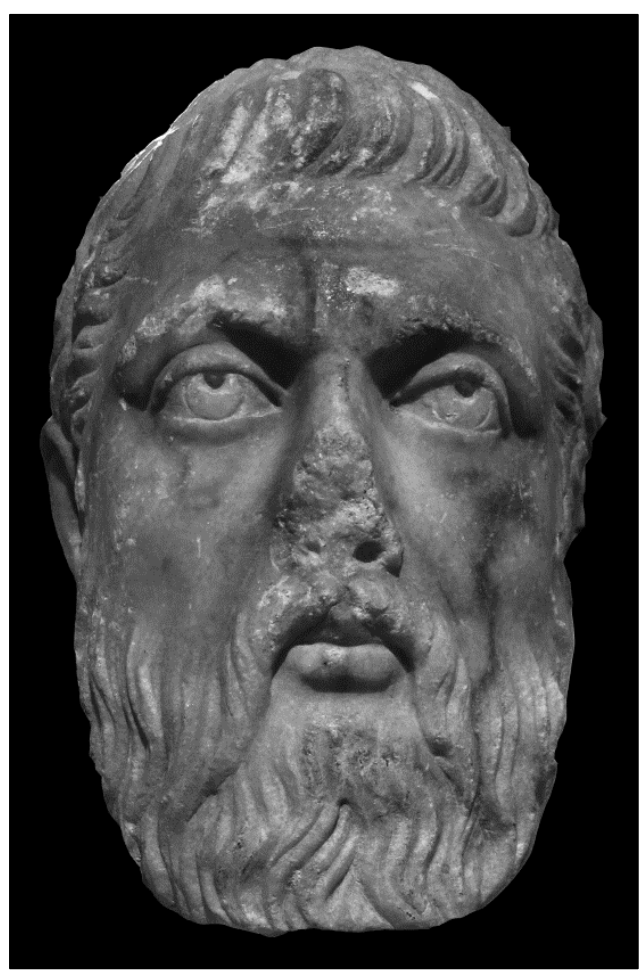

FIG. 16 - Portrait head of Plato, front. Christie's New York, 2012. Photo author.

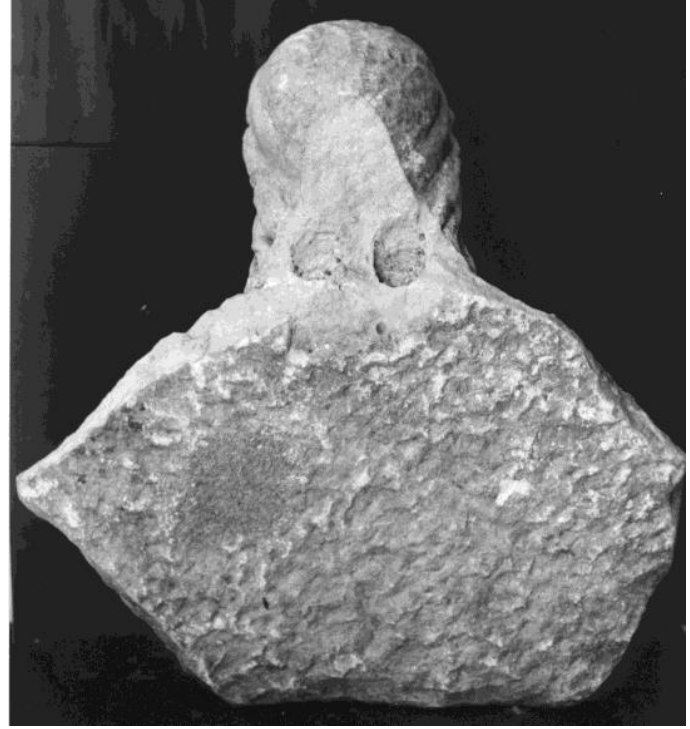

FIG. 15 - Back view, of head. Shield portrait of BornovaHeidelberg type from Bornova. Izmir Archaeological Museum.

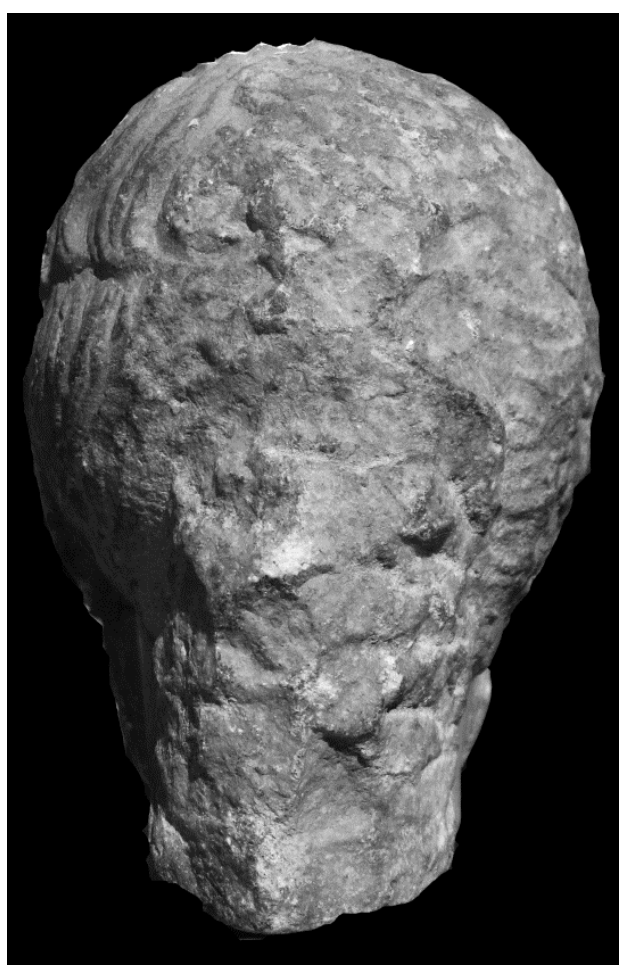

FIG. 17 - Portrait head of Plato, back. Christie's New York, 2012. Photo author. 


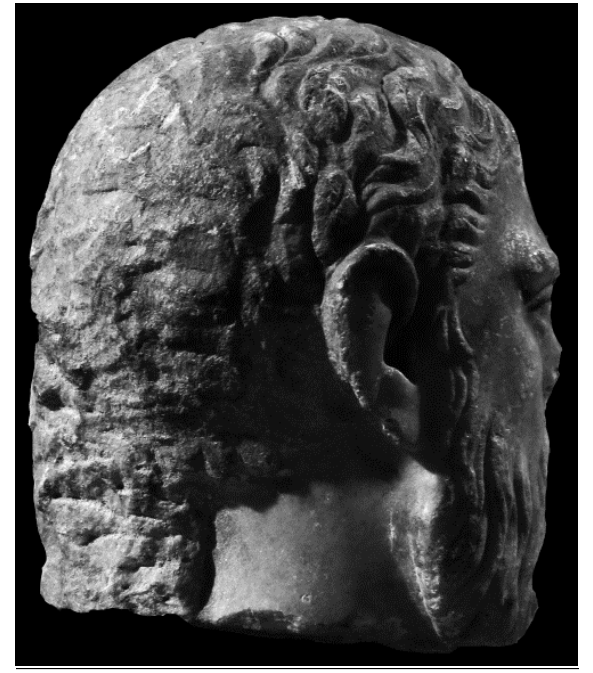

FIG. 18 - Portrait head of Plato, right profile. Christie's New York, 2012. Photo author.

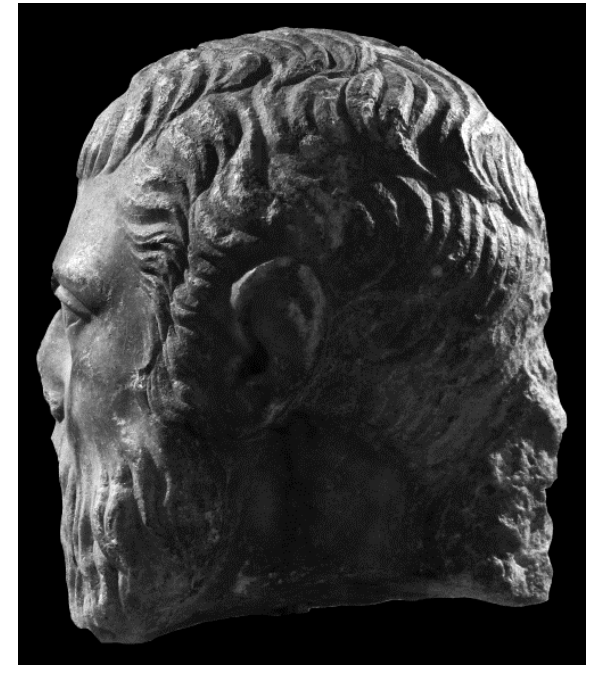

FIG. 19 - Portrait head of Plato, left profile. Christie's New York, 2012. Photo author. 